
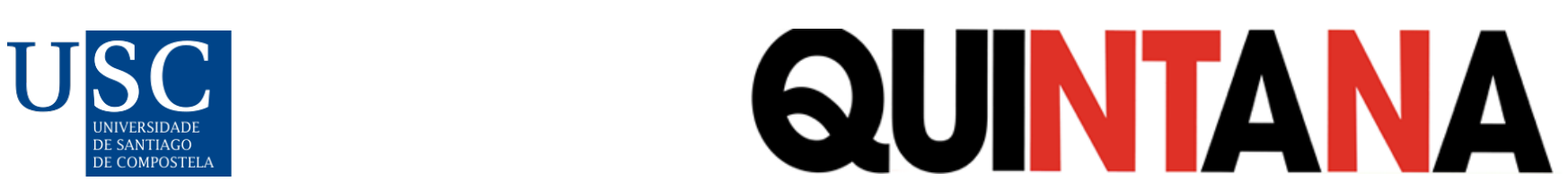

Quintana: revista do Departamento de Historia da Arte, (20), 2021. ISSN-e: 2340-0005

https://doi.org/10.15304/quintana.20.8070

Tema

\title{
VISUALIZANDO FORMAS, ESPACIOS Y CONTENIDOS EN LA RUTA JACOBEA: COMPOSTELA Y SAHAGÚN EN TRES DÉCADAS PRODIGIOSAS (1080-1110) ${ }^{1}$ \\ VISUALIZING FORMS, SPACES AND CONTENTS ON THE JACOBEAN ROUTE: COMPOSTELA AND SAHAGÚN IN THREE WONDERFUL DECADES (1080-1110)
}

\author{
José Luis Senra ${ }^{1,}$ (iD \\ ${ }^{1}$ Universidad Complutense de Madrid, España \\ a joseluis.senra@pdi.ucm.es
}

\section{Resumen}

Una vez reunificados los reinos de León, Galicia y Castilla, durante el último tercio del siglo XI el eje territorial comprendido entre los Pirineos y la vertiente atlántica experimentó profundos cambios en todos los órdenes. Dentro de un contexto de reforma gregoriana la autoridad ejercida por el rey Alfonso VI fue fundamental para que importantes cambios se impusieran. Por su parte, tanto obispos como abades establecieron reformas internas entre las cuales el cambio de rito litúrgico fue la de mayor importancia y dificultad. En riguroso paralelo y de modo más o menos simultáneo las estructuras arquitectónicas autóctonas comenzaron a ser sustituidas por otras más espaciosas y complejas. Sin embargo, se produjeron excepciones. A la luz de ese contexto, en este trabajo se analizarán las que probablemente fueron más poderosas instituciones de fines del siglo XI: la catedral de Santiago de Compostela (A Coruña) y la abadía de los Santos Facundo y Primitivo de Sahagún (León).

Palabras clave: Arte Románico; Monasterio de Sahagún; Catedral de Santiago de Compostela; Camino de Santiago.

\begin{abstract}
Following the reunification of the kingdoms of León, Galicia, and Castilla, during the last third of the eleventh century, profound changes occurred in all aspects across the territorial axis from the Pyrnees to the Atlantic coast. Within the context of Gregorian Reform, the authority exercised by King Alfonso VI was a crucial factor for the imposition of important changes. Likewise, both bishops and abbots undertook internal reforms, among which the change in liturgical rite was at once the most significant and the most difficult. In direct parallel and nearly simultaneously, the local architectural forms began to be replaced with other structures that were more spacious and complex. However, there were telling exceptions. It is within this context that the present study analyzes the two institutions that were probably the most powerful of all at the end of the eleventh century: the Cathedral of Santiago de Compostela (A Coruña) and the Abbey of Saints Facundo and Primitivo de Sahagún (León).
\end{abstract}

Keywords: Romanesque Art; Abbey of Sahagún; Cathedral of Santiago de Compostela; Way of St. James. 
Partiendo de su elevación a arquetipos de un contexto creativo singularmente bullicioso, durante los años finales del siglo XI, la mutación litúrgica institucional aplicada a los centros de poder más punteros del reino de León-Galicia y Castilla fue acompañada por un cada vez más sofisticado lenguaje visual. Es bien conocido que así como en otros territorios hispanos este proceso se produjo tiempo antes y de un modo aparentemente más armónico, si tal adjetivo es posible aplicarlo en las coyunturas de cambio, en estos tres reinos unidos desde 1073 las mutaciones impuestas desde esa misma década se hicieron desde una 'real' contundencia.

Para ello se propondrá un recorrido por aspectos convergentes en dos representativas y carismáticas instituciones hispanas: la catedral de Santiago de Compostela y el monasterio de los Santos Facundo y Primitivo de Sahagún. Los denominadores comunes que presentan no son pequeños. Ambos surgieron de sendos Locus Sanctorum: la catedral compostelana, reivindicadora de los restos del apóstol Santiago, y la iglesia monástica de Sahagún, custodia de los hermanos Facundo y Primitivo, mártires del siglo III. Uno y otro fueron promocionados desde su inicio por la monarquía astur-leonesa. Los dos generaron extensos dominios territoriales. Desde fines del siglo XI ambos experimentaron mutaciones profundas tanto en su seno institucional como en sus relaciones externas. En fin, rebasada esa centuria, en la segunda década del siglo XII los dos fueron protagonistas de las más importantes rebeliones urbanas acontecidas en los tres reinos unificados que produjeron daños en sus respectivos patrimonios muebles e inmuebles. Por su importancia, representatividad y sus convergencias históricas, Compostela y Sahagún posibilitan una excelente visión didáctica del fenómeno.

El contexto general en el que se va a centrar la parte nuclear de este trabajo se ubicará en el reinado de Alfonso VI (1073-1109) con puntuales incursiones hacia la crisis sobrevenida tras su óbito que, lentamente superada, supuso un hiato en la dinámica de los reinos. Gobierno que, no hay duda, proyectó y puso los cimientos de un verdadero renacimiento creativo plenamente asentado con la estabilidad del reino en la tercera década del siglo XII. En este sentido es elocuente el dibujo de prosperidad que, a modo de acta notarial, traza con claridad la parte quinta del Liber Sancti Iacobi (ca. 1130) y al que se podría aplicar la ampulosa e hiperbólica sentencia del cronista borgoñón Raúl Glaber (ob. 1047) -más retórica que real- del manto de iglesias que habría cubierto el paisaje europeo una vez sobrepasado el milenio Es notorio que el fervor constructivo del siglo XII, con sus implicaciones de articulación de territorios, de poder y de prestigio monástico y episcopal, no tiene parangón posible en el pasado peninsular desde el fin de Imperio romano.

En lo que respecta a estas dos grandes sedes institucionales, Compostela y Sahagún manifiestan con intensidad divergente la implementación a fines del siglo XI de fórmulas ajenas a la tradición local. La importancia de este fecundo periodo para ellas no fue pequeña en tanto fundamentó las bases para la señalada expansión monumental posterior; periodo además en el que la ruta de comunicación que unía a ambos alcanzó entonces su momento de consolidación. Con todo, es de rigor subrayar que contamos con un elevado déficit de conocimiento material: es el caso del monasterio de Sahagún del que apenas quedan restos visibles. Por otro lado, tanto de una como de otra institución, apenas nos ha llegado el ajuar litúrgico que completaba y definía sus estructuras templarias, carencia no banal por cuanto condiciona no poco su conocimiento orgánico e íntegro de su funcionamiento a partir de su intrínseca naturaleza habitable e hiperfuncional. Al fin y al cabo, el espacio sacro que trataba de configurarse buscaba un ordenamiento social fundamentado en el valor percepción asociado a un elemento de gran potencial: la capacidad de alentar estados de ánimo en los individuos que accedían a ellos ${ }^{2}$. Desde diferentes perspectivas pero con un poderoso 
denominador común -el peso de las reliquias-, ambas estructuras generaban un potente clima de cohesión social. Tal clima sustentaba un rígido régimen de subordinación de las poblaciones a la autoridad del obispo y del abad respectivamente, si bien, una vez liquidada la autoridad laica, la vulnerabilidad de ambas figuras quedó muy expuesta: tanto Compostela como Sahagún vieron cómo su supremacía se disolvía de modo puntual pero dramático.

En fin, para reducir el impacto de las referidas ventanas de desconocimiento se tendrán en cuenta cuatro expresivas fuentes documentales de comienzos de la primera mitad del siglo XII: la Historia Compostelana (en adelante HC), el Liber Sancti Iacobi (en adelante LSI), la Primera Crónica Anónima de Sahagún (en adelante PCAS) ${ }^{3}$ y la llamada Historia Legionense ó Seminense (en adelante HLS) ${ }^{4}$; ésta, al igual que la anterior, quizá también redactada en el monasterio de Sahagún ${ }^{5}$

\section{MONJES Y CANÓNIGOS EN UN CONTEXTO EXCEPCIONAL: EL REINADO DE ALFONSO VI}

En el curso del gobierno del rey Alfonso VI el eje territorial comprendido entre los Pirineos occidentales y el extremo atlántico de Galicia experimentó un elevado desarrollo en todos los órdenes -político, social, económico- sin precedente posible desde que colapsara el reino visigodo. Los cuarenta años alfonsíes pusieron en marcha fórmulas culturales más complejas que las autóctonas motivadas por una decidida voluntad de homogeneidad en relación al ecosistema sobre el que venía rodando el continente desde el siglo IX. En la dimensión estrictamente sacra, entendida esta como un indivisible binomio político-religioso, las hechuras o principios constitutivos de la arquitectura religiosa fueron haciéndose igualmente más elaboradas en base a la demanda de una curva demográfica creciente a lo que acompañaba unas formas de devoción alimentadas por medios de transmisión cada vez más eficaces; en rigurosa simetría las comunidades religiosas incrementaron sus vocaciones y la nueva liturgia practicada elevó su complejidad. La retroalimentación del conjunto de estas pulsiones fue clave para que se activase una renovación arquitectónica.

Es obvio que la arquitectura religiosa perseguía la equidistancia máxima entre tiempo finito y eternidad desde una realidad de partida: la consideración del templo como una estructura de compulsiva reactualización ritual y catalizadora tanto de experiencias religiosas íntimas como sobre todo colectivas. Con un contenido añadido de fuerte vocación didáctico-ideológica las nuevas estructuras significaron la emersión de formas de relación espacio-visuales inéditas hasta entonces, que en ocasiones se movieron entre la innovación y, como veremos, bien que en ocasiones puntuales, el más estricto conservadurismo. Estructuras que se regían desde una intensa interrelación entre espacio, imagen, letra y sonido y en las que el valor sensorial adquirió su plenitud y madurez en relación a un pasado autóctono menos dinámico. La puesta en marcha de edificios envolventes más amplios y complejos, parlantes a partir de su prolija iconografía, tuvo que asociarse en medida difícil de cuantificar con las nuevas relaciones político-sociales que se extendieron en este marco territorial. Como es de sobra sabido, los años setenta del siglo XI fueron fundamentales para la reunión de los reinos de León, Galicia y Castilla y, acto seguido, para la implantación del rito romano, importante aldabonazo tanto como refuerzo de costuras territoriales como para la nueva fiebre constructiva ${ }^{6}$. 
Un aspecto importante a considerar es el derivado de la crisis del reinado de Alfonso VI iniciada en sus años finales y consolidada de modo dramático tras su óbito. Por encima de un subjetivo por interesado valor retórico de contraste y de una cierta damnatio memoriae al que se somete la dificultad del final de un gobierno sin lugar a dudas abrupto y complejo al que, con todo, se evidencia cierto esquema providencialista, las expresivas fuentes documentales mentadas (todas ellas redactadas con posterioridad a 1109) dan fe de un unánime e intenso sentimiento de añoranza con respecto a un periodo floreciente. Solapadas por el conflicto entre la heredera del reino, Urraca (1109-1126) y Alfonso el Batallador (1104-1134), con la instalación de un quiebro del status hasta entonces no violentado, las revueltas urbanas que se produjeron en importantes señoríos eclesiásticos abocaron a las élites eclesiásticas a un importante sentimiento de vulnerabilidad. La mirada retrospectiva en clave nostalgia era inevitable.

En la península ibérica solo contamos con un edificio que aúne alta intensidad litúrgica, una comunidad religiosa muy amplia y el añadido de una superlativa carga devocional: la Catedral de Santiago. Asociada a la monarquía desde su mismo origen en la tercera década del siglo IX, el potencial de la institución era ya muy elevado en la primera mitad del XI cuando el obispo Cresconio (1037-1066) se encontró suficientemente sólido para reivindicar ante Roma su sede como apostólica. En su ambiciosa hoja de ruta no es improbable que contemplara la sustitución del viejo y reconstruido templo de Alfonso III (866-910). Cuando su sucesor, Diego Peláez (1070-1088), dio el paso en 1075, la solución ofrecida, extraordinaria, generó uno de los edificios más sofisticados de la época con un crisol de soluciones punteras provenientes de la más alta experimentación continental. Probablemente en su proceso constructivo la catedral se benefició del quinquenio de stand-by (1088-1093) producido por la deposición de Peláez a partir del cual se asistió a la mayor sofisticación que le insufló la segunda fase. Cuando esta avanzaba con un ritmo importante el joven obispo Diego Gelmírez (1100-1140) adaptó el coro de canónigos a la nueva realidad espacial. Con un convencional sentido simbólico que pivotaba sobre el número doce, según indica el LSI (V, 10) los incrementó de veinticuatro a setenta y dos $(12 \times 6)$ parangonando a sus clérigos con los discípulos nominados por Jesús de Názaret como misioneros (Lucas 10, 1-20); además, en la voluntad de interconectar AT y NT coincide con los setenta y dos repobladores de la tierra (Génesis 10, 1-32) ${ }^{7}$.

Tras la catedral de Santiago, la institución más destacada del reino fue el monasterio de los Santos Facundo y Primitivo de Sahagún. A solo 60 kilómetros al sureste de León, desde fines del siglo IX el monasterio se asoció igualmente a la monarquía convirtiéndose en un actor fundamental de legitimidad y de cohesión territorial del reino. El sólido espaldarazo de Alfonso VI una vez que en 1073 se hizo con las riendas de los tres reinos, León, Galicia y Castilla, elevó al monasterio a su máxima representatividad; más aún si cabe cuando el lugar fue convertido en frecuente sede regia (Palatium) y en el designado lugar de inhumación del monarca una vez reformado según los usos litúrgico-monásticos cluniacenses (1079-1080) en vez del dinástico de San Isidoro de León. Lamentablemente el conjunto monumental fue desmantelado prácticamente en su totalidad en la primera mitad del siglo XIX y tenemos un déficit muy elevado para su exacto conocimiento material en aquellos años. En relación al volumen de la comunidad monástica, no contamos con información hasta mediado el siglo XII cuando se registran treinta y tres monjes ${ }^{8}$, un número bajo tanto en relación a la importancia de la institución como en parangón respecto a otros centros monásticos del reino si bien en la segunda mitad del siglo el crecimiento fue, en líneas generales, importante en el conjunto de ellos ${ }^{9}$. 


\section{LOS ANTECEDENTES: COMPOSTELA Y SAHAGÚN ENTRE LOS SIGLOS IX Y X}

Según todos los marcadores documentales, hacia 820 se puso en marcha el culto a las supuestas reliquias de Santiago en Compostela y a fines de ese mismo siglo IX se constata que Sahagún era ya un enclave con devoción cultual a los mártires hispano-cristianos Facundo y Primitivo, si bien su existencia bien puede retrotraerse a época visigoda (siglo VII) ${ }^{10}$. La importancia de ambos lugares en este periodo lo pone de relieve el hecho de que fueron blanco de saqueos islámicos con consecuencias para sus iglesias: la de Sahagún estuvo afectada por dos ataques documentados: uno en $883^{11}$ y otro en 997. En el curso de este último fue también afectada la basílica de Santiago en Compostela ${ }^{12}$. Ambos acontecimientos quedaron intensamente grabados en la memoria de sus comunidades religiosas ${ }^{13}$.

Asimismo, como se ha indicado, el pasado de ambas instituciones, generadas sobre mausoleos santos, es decir, con reliquias no trasladadas, contó con el ascendiente real lo que hizo que, en mayor o menor medida, fueran importantes centros de legitimación y de proyección de poder. Tras su inventio, hacia 820, el mausoleo que constituía el locus sancti de Santiago fue dignificado con una pequeña construcción envolvente por Alfonso II (791-842) y a través de un grupo de edificaciones satélite $^{14}$; a fines del siglo siguiente Alfonso III (866-910) reseteó el lugar con un edificio más espacioso, "enriquecido con grandes honores y sacras vestiduras", inaugurado en $899^{15}$. El acta de consagración, más allá de la manipulación de la que fue objeto en base a amplificar sus dominios, subraya la obra realizada, sin duda de una singular calidad ${ }^{16}$.

Por su parte en el contexto de la expansión del reino astur por la meseta, en el ocaso del siglo IX, Alfonso III habría articulado el lugar de Sahagún con el concurso de una comunidad de monjes mozárabes conformando un señorío territorial sin parangón posible con otra institución monástica de León-Galicia y Castilla que, vertebrada en un eje norte-sur, llegó a abarcar desde la cordillera cantábrica al área de Zamora $^{17}$. Los siglos X y XI no hicieron sino reforzar este patrimonio que a partir de lo arquitectónico dio lugar a un importante conjunto que desgraciadamente conocemos de modo muy sesgado. Con todo, la documentación superviviente da buena cuenta de la notabilidad de su templo (templo mire magnitudines ornato o bien composito) ${ }^{18}$.

Las dos iglesias financiadas por Alfonso III debieron contar con proporciones semejantes Compostela 32 × 14 m.; no sin prudencia Sahagún 29 × $15 \mathrm{~m}^{19}$ - si bien, aunque simples ambas a partir de su rigurosa horizontalidad y distribución en tres naves, probablemente las elevaciones respondían a estéticas diferentes: la primera debió plegarse a las líneas de las iglesias ovetenses mientras que la segunda adoptaría la estética denominada con mayor o menor fortuna 'mozárabe' o de 'repoblación' 20 (figs. 1 y 2). 
Fig. 1. Planta iglesia de Santiago financiada por Alfonso III (J. Guerra Campos)

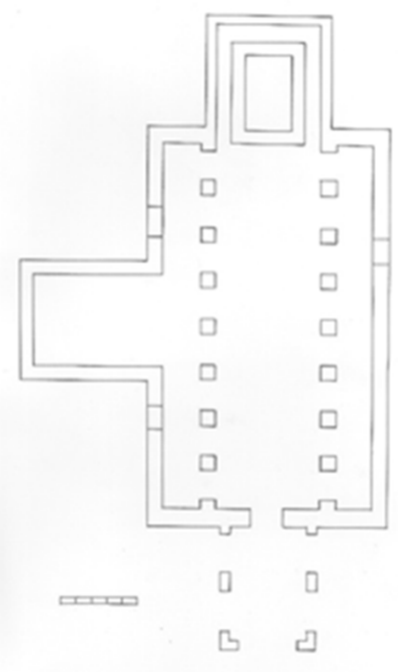

Fig. 2. Planta hipotética de la iglesia de Sahagún financiada por Alfonso III con añadido de bloque occidental y panteón de Alfonso VI (J. L. Senra)

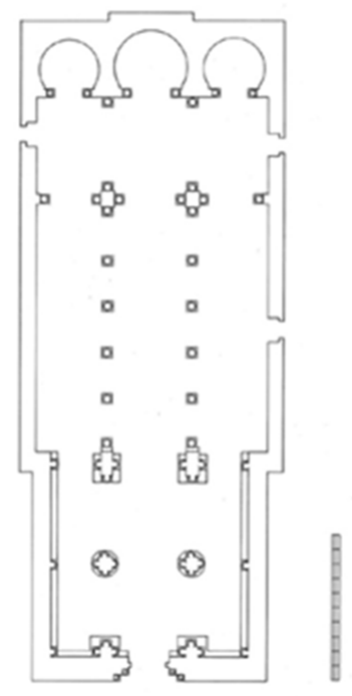

Sin embargo, la andadura por el tiempo de ambos edificios fue divergente. Si bien la compostelana fue derribada en tres fases, primeramente su cabecera a medida que la girola románica ganaba terreno (ca. 1093-1098), posteriormente el mausoleo apostólico (ca. 1104-1105) y finalmente su cuerpo de naves (1112). Como veremos, el templo prerrománico de Sahagún extendió su supervivencia una centuria (figs. 3 y 4). 
Fig. 3. Planta hipotética de la cabecera de la catedral de Santiago hacia el año 1095 (J. L. Senra)

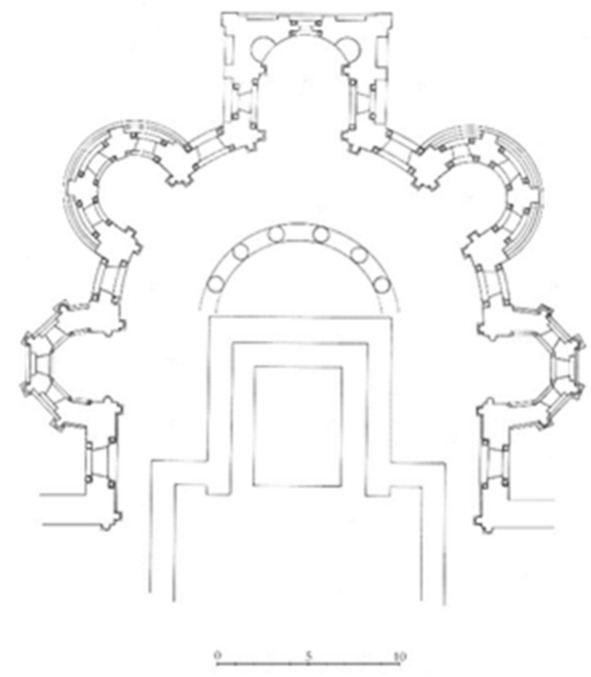

Fig. 4. Corte longitudinal de la catedral de Santiago hacia el año 1105 (J. L. Senra)

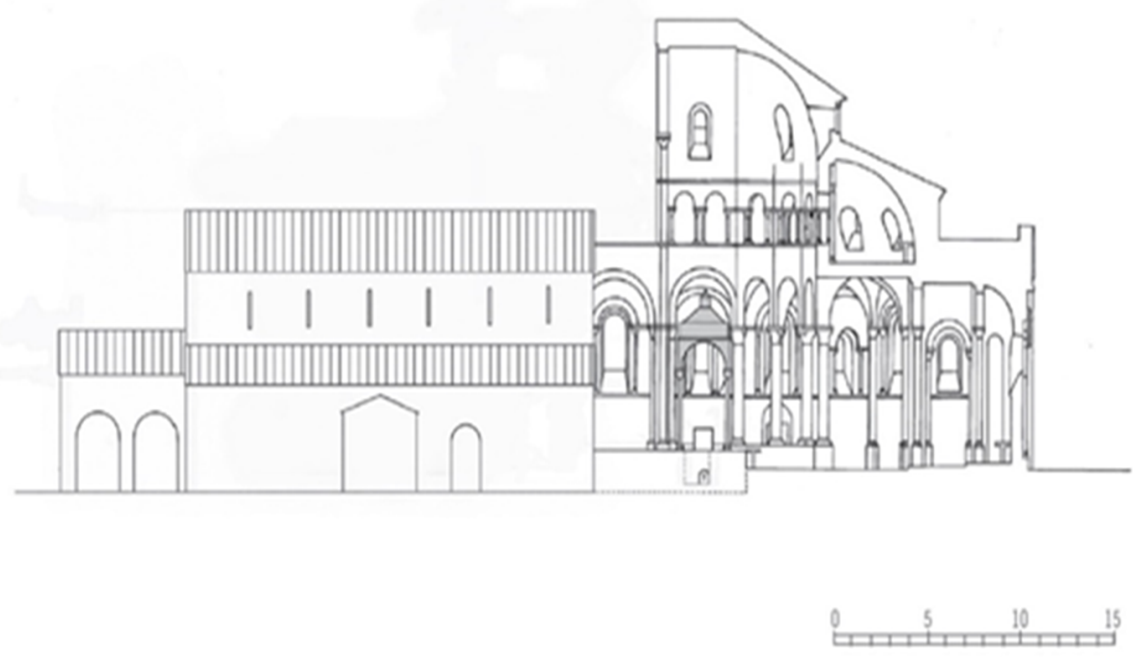

Un aspecto de importancia en la consideración de Compostela y Sahagún se encuentra en la HLS, mediante un nítido ejercicio de edilicia real, exaltaba en riguroso paralelo, el doble impulso de Alfonso III, tanto en pro de la basílica compostelana como de la erigida sobre el locus de Facundo y Primitivo ${ }^{21}$. Sin embargo, omitió otras importantes acciones de mecenazgo asociadas al monarca astur perfectamente documentadas. Es por ello que, como fuente inconclusa que es y cuyo objetivo último era elaborar un relato de memoria y exaltación de Alfonso VI, haciendo un parangón con el que sin duda es el monarca más ponderado de la crónica -Alfonso III- es inevitable preguntarse si no pudiera haber constituido una suerte de prefiguración retórica respecto a lo 
que dos siglos después haría el conquistador de Toledo promocionando tanto Compostela como Sahagún ${ }^{22}$. Lamentablemente no podemos ir más allá de la conjetura razonable.

\section{LA SUJECIÓN A UN NUEVO ORDEN INSTITUCIONAL DE COMPOSTELA Y SAHAGÚN}

Compostela y Sahagún pusieron en marcha una elaborada teología política de rotundo sesgo gregoriano en la que, como funcional correa de transmisión, pivotaba con una sólida presencia la orden cluniacense. Aunque en la catedral gallega el primer paso en pro de la homogeneización litúrgica lo dio Diego Peláez en 1075 al poner en marcha el nuevo edificio catedralicio según parámetros ajenos a lo local, no mucho después Cluny se alzó como un influyente y decisivo revulsivo canalizador de energía tanto en la sede apostólica como en Sahagún. Respecto a Compostela a partir de los obispados del cluniacense Dalmacio (1094-1095) y de su epigonista y sucesor Diego Gelmírez (1100-1140). En otro lugar se ha subrayado la importancia que el breve pero intenso episcopado de Dalmacio pudo haber tenido como impulsor tras unos años de decadencia una vez depuesto Peláez: más allá de la consecución del traslado de la sede de Iria y del privilegio de exención, es fundamental tener presente el ascendiente formativo breve pero intenso que pudo haber supuesto para un joven Gelmírez que una vez ocupado el cargo tras el óbito de Dalmacio, subrayó un estrecho vínculo con la abadía borgoñona ${ }^{23}$. En este sentido, dado que Dalmacio heredó el proceso de construcción, es muy de considerar el rol desempeñado como diseñador de los contenidos sacros del edificio -eclesiología de los espacios-, luego desarrollados por su longevo sucesor (1100-1140) ${ }^{24}$.

Por su parte, el monasterio benedictino de Sahagún fue reformado en 1080 por designio real con las coordenadas benedictinas cluniacenses y la liturgia romana: a partir de tal movimiento Alfonso VI establecía un arquetipo monástico de prestigio ${ }^{25}$. Es muy elocuente que, rompiendo la tradición de la sede regia de San Isidoro en León, ese mismo año un documento de su cancillería indicaba sus deseos de ser allí enterrado ${ }^{26}$. En relación al proceso de adaptación a los nuevos signos contamos con marcadores nítidos del rápido tránsito de la comunidad desde unas formas tradicionales a otras nuevas ${ }^{27}$. Sahagún además se convirtió en prioritaria sede de invierno por parte de Alfonso y allí estableció su residencia palatina, probablemente, en el área oeste del monasterio, junto al bloque occidental $^{28}$. Por otro lado las riendas de la institución fueron entregadas a un carismático monje cluniacense, Bernardo de La Sauvetat que en poco más de un quinquenio (1080-1086) trazó el modelo monástico reformado para sus sucesores obteniendo privilegios fundamentales como, siguiendo la estela de Cluny, la inmunidad monástica (1080) y aun después de dejar el cargo, su ascendiente sobre la institución fue muy elevado ${ }^{29}$. No es de descartar que el propio Bernardo, desde 1086 convertido en arzobispo de Toledo, fuera quien sugiriera en 1094 la conveniencia de que la sede apostólica fuera reordenada a través de la designación de un compañero de su orden. Con todo no pudo calcular que el meteórico ascenso de Compostela con ansias de sede primada acabaría por confrontarle con la ambición de un todavía inofensivo Gelmírez ${ }^{30}$.

Para considerar la elevada posición de Bernardo y su misión reformista es ilustrativa la carta del abad de Cluny, Hugo, a él dirigida tras la toma de Toledo (1085), en la que se despliega un alegato en términos laudatorios de la perfección de la Iglesia cluniacense en relación a una nación 
bárbara, la hispana, con clérigos que militan en un tóxico contrapunto respecto al idílico modelo apostólico (apostolorum ac primitive Ecclesia) al que insta a establecer en su episcopado ${ }^{31}$. Sabemos a través de Rodrigo Jiménez de Rada, arzobispo de Toledo (1210-1247), del preponderante papel jugado por Bernardo en la nominación de candidatos a sedes episcopales del reino, vértices de poder fundamentales para revertir el viejo orden eclesiástico ${ }^{32}$; acabo de hacer referencia a su posible mediación en la elección de Dalmacio en Compostela. Bernardo diseñó desde cero la sede de Toledo y en pro de contar con un espacio para el buen desempeño del culto, al igual que hiciese con el templo prerrománico de Sahagún al que tuvo que adaptarse, en este caso con un importante incremento de exigencia, reconfiguró el interior de la ocupada mezquita mayor reorganizando espacios y habilitando altares jerarquizados ${ }^{33}$. El mismo Jiménez de Rada dejó escrito que para conformar el nuevo cabildo catedralicio Bernardo se proveyó de monjes de Sahagún ${ }^{34}$.

Sin embargo, desde un denominador común de inicio, la presencia de dos edificios unidos por el patrocinio regio, Compostela y Sahagún optaron por dos itinerarios bien divergentes. Compostela consideró necesario sustituir la vieja iglesia de Alfonso III por otra más adaptada al decoro de un episcopado sumido en una carrera ascendente a partir de su consideración apostólica; además la estructura era indudablemente disfuncional para las exigencias de culto y devoción que traía consigo la peregrinación continental. Por su parte como veremos más en detalle, Sahagún, un modelo menos destacado a partir de la trascendencia de sus reliquias pero más próximo a los intereses del poderoso monarca del momento, optó por mantener la estructura prerrománica priorizando por encima de cualquiera otros valores el prestigio y la memoria de un pasado legitimador como era el astur-leonés. En esta determinación de corte personalista dado su íntimo vínculo con el monasterio necesariamente tuvo que tener algún peso un hecho fundamental: Alfonso revirtió la partición territorial paterna reuniendo los tres reinos sesgados tras cinco años de conflicto fratricida (1067-1072). Es significativo que una de las primeras acciones de Sancho II de Castilla tras derrotar provisionalmente a Alfonso en 1072 fuera emitir un diploma a favor del monasterio de Sahagún ${ }^{35}$.

\section{DE LA LITURGIA DE SACRALIZACIÓN DE UN NUEVO EDIFICIO (LAPIS ANGULARIS), LA ACTIVACIÓN DE SUS ALTARES (CONSACRATIO) Y LA INAUGURACIÓN COMPLETA (DEDICATIO)}

Desde la omnipresencia de los arquetipos constructivos bíblicos como el Templo de Salomón o la Jerusalén Celeste, el concepto teológico de piedra angular está intensamente arraigado en la exégesis cristiana ${ }^{36}$ y su proyección, incluso figurativa, ya se observa en la iconografía más temprana ${ }^{37}$. Injertado en la praxis constructiva, mediado este ritual se sacralizaba la materialidad del edificio a través de la conexión con el influyente pasaje de la Carta a los Efesios en el que se concibe a Cristo como piedra angular sobre la que se sustenta el conjunto de los fieles (ecclesia) ${ }^{38}$. Se trataba por tanto de envolver a la construcción con una metáfora relativa a la asamblea reunida de fieles siguiendo los trazos alegóricos marcados por autores tan influyentes como Beda el Venerable (ca. 672-735) a partir del anclaje del edificio en el solar yermo ${ }^{39}$.

Lamentablemente apenas contamos con documentación sobre estas ceremonias específicas aplicadas en lugares concretos y menos aún con testigos materiales de piedras angulares de 
edificios no ya de este periodo que tratamos, sino, en general, del conjunto de la Edad Media. Codificada en la segunda mitad del siglo X en ámbito otoniano (Pontifical romano-germánico), la ceremonia de colocación de la lapis angularis -y esto es importante subrayarlo- no marcaba necesariamente el inicio de las obras en el sentido literal ${ }^{40}$; determinada un momento que se consideraba propicio, representativo y simbólico para bendecir la emersión del edificio ${ }^{41}$. Es decir, la construcción podía haberse iniciado un tiempo antes de que se singularizara su sacralización; en este sentido contamos con un ejemplo muy ilustrativo sobre este proceder: en la iglesia monástica de San Miguel de Hildesheim (Sajonia) la datación de su conservada piedra angular en 1010 ¿es prueba de que la construcción comenzó en ese año o tan solo documenta un momento específico de una obra que pudo haber comenzado antes? Como bien razona Enno Bünz, la data de 1010 ante todo definía la instauración de la nova ecclesia $D e i^{42}$.

La tendencia en las grandes construcciones religiosas era que la jerarquía social, el obispo y el monarca, presidieran el acto litúrgico fundamentado en la colocación de una o varias piedras (12) grabadas de modo variable, pero en la que solía ser normativo la presencia de al menos una cruz. Un ilustrativo caso de piedra angular conservada es la ya mentada de la iglesia de San Miguel de Hildesheim en la que constan los nombres de Benjamín y de Mateo, hijo más joven de Isaac y primer evangelista, respectivamente; junto a ello las iniciales del obispo Bernward y la fecha $(1010)^{43}$. Una vez más la sempiterna dialéctica entre Antiguo y Nuevo Testamento desarrollada por la patrística ${ }^{44}$ (fig. 5).

Fig. 5. Piedra angular (lapis angularis) de la iglesia monástica de Saint-Michael de Hildesheim (Foto: J. L. Senra)

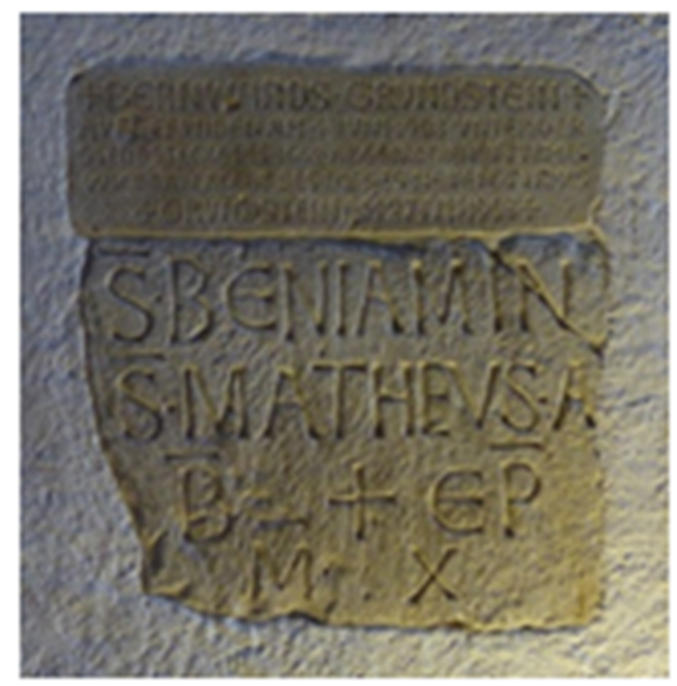

En lo que se refiere a la Catedral de Santiago hace unos años razoné mi punto de vista según el cual la ceremonia de colocación de la llamada piedra angular (lapis angularis) tuvo lugar el 11 de julio de 1078, fecha que registran y en la que convergen tanto la HC (I, 78) ${ }^{45}$ como el LSI $(\mathrm{V}, 9)^{46}$ a la hora de establecer el inicio de la nueva obra de la catedral románica ${ }^{47}$. Un tercer marcador indirecto, la fecha inscrita en el umbral de la portada de Platerías, consigna el mismo día y el mismo mes si bien no existe unanimidad para determinar el año ¿1078 ó 1103? ¿Aludiría a la ceremonia 
inaugural de la obra o a la datación del acceso meridional de la catedral ${ }^{48}$ Lo verdaderamente trascendente es que cuando ambas fuentes subrayan el inicio del edificio y explicitan una data específica -como he indicado-, mediante la acción litúrgica de la lapis angularis se trataba de fijar el momento adecuado para sacralizar el lugar y el propósito religioso de la nueva estructura a partir de la simbólica disposición de unidades pétreas bendecidas. Y como confirman de modo palmario tanto la Concordia de Antealtares (1077) como la inscripción retrospectiva de la capilla del Salvador (1075), las obras se iniciaron tiempo atrás si bien resulta complejo saber en qué punto exacto se encontraban en el momento de redactarse aquél documento ${ }^{49}$. En sus geométricos comentarios sobre el edificio Serafín Moralejo consideró que a partir del párrafo más explícito sobre los trabajos realizados -con la simultaneidad de uso de tiempos verbales diversos, construebatur y construeretur- tan solo podría especularse "con posibles obras en curso en la capilla de San Pedro" ${ }^{50}$. Por tanto es harto complicado concretar la situación de la cabecera tanto en agosto de 1077 (Concordia) como en julio de 1078 (noticia de la HC y del LSI sobre el 'inicio de la obra') si bien, como se indicó líneas atrás, la elevación parcial no era en absoluto óbice para la celebración del acto litúrgico de la lapis angularis. Es obvio que si al analizar acontecimientos sacros pertenecientes a un periodo como el medieval, intensamente simbólico y regido por el cómputo litúrgico y la percepción anagógica, extrapolamos nuestro pensamiento cartesiano asociando tiempo sagrado y tiempo secular, cometeríamos un muy abultado error hermenéutico ${ }^{51}$. En fin, cuando dos fuentes documentales tan vigorosas como las señaladas convergen en datar el inicio del edificio el 11 de julio de 1078 lo más sensato es darles credibilidad y considerar que aludían a la sacralización del artefacto arquitectónico que se construía. Harían estricta y palmaria referencia al comienzo del más elevado y fundamental valor del edificio religioso: su dimensión sagrada y su arraigo en el colectivo de fieles.

La coincidencia con la festividad de ese día del calendario litúrgico romano, que en el año 1078 fue jueves, con la festividad, intensamente benedictina, del traslado de las reliquias de Benito de Nursia de la abadía de Montecasino a la de Fleury, junto al Loira, no es complemento argumental baladi $^{52}$. Se trataba de establecer un marco contextual adecuado para la afectada comunidad monástica de Antealtares, protagonista de primer orden en aquel acto en tanto garante primigenia del decoro de la basílica del apóstol Santiago. Más allá del celo con el que se escogían los días de las ceremonias litúrgicas, estando además tan implicada en esta operación sustitutiva del locus sancti, la comunidad benedictina de San Salvador de Antealtares, no parece que la elección de ese día del calendario litúrgico fuera arbitraria. La Concordia de Antealtares indica como, para poder establecer la cabecera del nuevo templo catedralicio, los monjes fueron conminados a desplazar su monasterio más al Este. Junto a ello, según los términos jurídicos establecidos en ese acuerdo entre el cabildo catedralicio y los monjes de Antealtares, la capilla axial de la nueva catedral, dedicada al Salvador, pertenecería junto a las anexas de Pedro y Juan, al monasterio benedictino. Esta triple advocación se derivaba de la propia cabecera de Antealtares cuyos patrones acabarían siendo transferidos a los tres ábsides románicos cuando finalmente en 1105 se consagraron los altares de la girola y tres de los abiertos en el transepto.

Dada la trascendencia del acontecimiento en una institución como la catedral apostólica y del permanente impulso de involucrar en tales ceremonias, no solo al pueblo sino igualmente a jerarcas laicos (ecclesia), se hace difícil que no estuviera presente el monarca participando de manera activa y significada. Más aún cuando en 1075 habría alentado la puesta en marcha del nuevo edificio. Aunque la documentación regia conservada no permite precisar la ubicación de 
Alfonso VI en la primera quincena del mes de julio de 1078, es perfectamente viable su estancia en Compostela ${ }^{53}$. Si así fuera ¿podemos saber algo del modo en pudo haber participado en la ceremonia? Un referente bastante próximo en el tiempo lo constituye el acto de la lapis angularis realizado en la colegiata de Vysehrad, cerca de Praga, en el año 1070, es decir, solo ocho años antes que el caso compostelano. Según la Crónica de Cosme de Praga, el duque y posteriormente rey Bratislao II de Bohemia (1061-1092) trasladaría doce cestas con piedras sobre sus hombros en honor del Salvador emulando con ello a lo que supuestamente habría realizado el emperador Constantino en la iglesia de Roma ${ }^{54}$. Como vimos líneas atrás, las implicaciones del número doce en la dialéctica de interrelación bíblica son múltiples y bien conocidas: desde los doce hijos de Jacob, las doce tribus de Israel, los discípulos de Jesús de Nazaret o las doce puertas de la Jerusalén Celeste ${ }^{55}$. Por otro lado -y para el marco que nos interesa- doce eran los prelados que registran las crónicas hispanas para llevar a cabo el acto de unción regia en tanto el monarca se asociaba con Cristo y al mismo tiempo era el mismo Cristo quien sancionaba su elección ${ }^{56}$.

Aunque carecemos de asistencia documental del desarrollo de la presumible ceremonia de la lapis angularis en Compostela, es muy fácil que afectara a la capilla axial dedicada al Salvador. Como se ha indicado, la tradición evangélica hace de Cristo la piedra angular sobre la que gira y se sustenta la Iglesia. Y el proyecto catedralicio procedió a singularizar la morfología de la capilla, la única ortogonal y más profunda del edificio, destacándola además a través de una articulación mural y una ornamentación escultórico-iconográfica más prolija que las otras ocho de la catedral ${ }^{57}$. Baste recordar la presencia en su interior de dos columnas declaradamente divergentes en relación al resto de la catedral -fustes de granito pardo y capiteles de mármol- ${ }^{58}$, el modulado arco que las une ${ }^{59}$, las exedras o la alternancia de arcos semicirculares y en mitra en el exterior o, en fin, la propia iconografía en sus márgenes del rey y del obispo, piezas capitales en la ceremonia a la que nos referimos. En fin, acabo de hacer referencia a la asociación litúrgico-simbólica entre el monarca y Cristo desde el mismo acto de la unción ${ }^{60}$.

Una cuestión complementaria a abordar es la en absoluto extendida dedicación al Salvador cuya referencia más obvia y representativa se encontraba en la Catedral de Oviedo cuyo altar principal funcionaba con ese patrocinio ${ }^{61}$ en una rotunda simultaneidad respecto a la extensión de esa misma advocación litúrgica en el mundo carolingio ${ }^{62}$. En el caso compostelano es necesario hacer notar que responde a una herencia institucional: en la primera configuración del locus sancti el rey Alfonso II impulsó la fundación de una comunidad de monjes que se debían ocuparse de mantener el decoro litúrgico de la basílica apostólica ${ }^{63}$. La cabecera de la anexa iglesia monástica incluía la presencia de altares del Salvador, Pedro y Juan. Pero el clímax sacro cristalizó una vez que la catedral asumió esta triple significación evangélica en su cabecera: entonces las advocaciones de Pedro y Juan asociadas a la del altar mayor de Santiago y al de Cristo-Salvador, configuraron una semántica trascendente y mística: la Transfiguración.

En cualquier caso, si la elevación de la capilla del Salvador estaba en marcha en 1078, en ese entorno se comenzaría a ensamblar la escultura monumental cuya dirección iconográfica, dada la comentada trascendencia del espacio, no parece que fuera en absoluto neutra o aleatoria. De hecho configura un caso excepcional a partir de la presencia en el arco de acceso a la capilla de la figura del rey Alfonso VI coronado, en manifestación anagógica, sujeto por ángeles ${ }^{64}$; una suerte de preludio de la antífona del rito funerario a través del que se invoca el traslado del difunto al Paraíso 
mediante la acción de los ángeles (angeles in paradisum) ${ }^{65}$. Asimismo se constata una voluntad de conexión dinástica a través de la inyección de un recurso de memoria: en una inscripción conmemorativa del muro meridional de la capilla se explicita la fundación del locus por parte del rey Alfonso II. Es relevante que este mismo procedimiento podía verse desde el siglo IX en el ábside central de la catedral de Oviedo cuyo altar, como ya se dijo, también estaba dedicado al Salvador. Allí constaban epígrafes alusivos a la acción germinal en el edificio por parte de Fruela (757-768) y del propio Alfonso II (791-842) ${ }^{66}$. Por lo tanto, entre la catedral románica y la de Oviedo, es decir, dos edificios paradigmáticos del reino, concurría una explícita convergencia en la ya comentada voluntad asociativa de memoria y mecenazgo real junto a la advocación del altar. De nuevo la asociación del poder monárquico con Cristo; desde fines del siglo X contamos con imágenes explícitas de sacralización del poder real o imperial, pautado en el ordo de la coronación, mediante la sanción por parte del Salvador ${ }^{67}$.

Respecto a la consagración de 1105 sabemos por la HC $(\mathrm{I}, 19){ }^{68}$ que inauguró la actividad litúrgica de la cabecera una vez que, tras el aletargamiento 1088-1094, fue rematada por el impulso del arquitecto Esteban. Esta fase constructiva no solo era completamente solidaria con la calidad de la obra sobre la que emergía, la proyectada por sus predecesores Bernardo y Roberto; igualmente se alineaba con la explosión de los modelos arquitectónicos finiseculares más prestigiosos del continente incluso superándolos en muchos marcadores de calidad. A la luz de su materialidad no puede dudarse que Esteban produjo una sofisticación del proyecto precedente por cuanto resultaría una entelequia metodológica considerar el plan inicial presentado en 1075 por Bernardo y Roberto como cerrado y aplicado en detalle durante el extenso gobierno de Gelmírez. Esteban, como Mateo posteriormente, fue consciente de la envergadura de la obra que continuaba y, partiendo de las líneas matrices de sus predecesores, introdujo una mayor complejidad al proyecto (ritmos arquitectónicos binarios) y una inédita organización del trabajo (logística de taller) ${ }^{69}$. La anexión correctora del mencionado Mateo entre 1168 y 1211 es ilustrativa tanto desde lo particular (plena conciencia de la calidad de la obra) como de lo universal (carácter intensamente orgánico de los crecimientos estructurales de calado como es el caso de la catedral gallega). La impronta de Esteban se manifestó de modo directo -como es sabido- en su proyecto de la nueva catedral de Pamplona en el mismo periodo finisecular y posiblemente, a partir de la querencia por las formas poligonales mediada una suerte de mímesis de prestigio, en otros edificios de modo inmediato como la iglesia monástica de San Zoilo de Carrión (torre noroccidental) y en otros muchos en sus respectivas áreas de influencia directa a lo largo del siglo $\mathrm{XII}^{70}$.

En relación a la iglesia monástica de Sahagún, en 1099 la PCAS documenta su consagración "llamados muchos obispos y abades, y muchos caballeros y nobles (...) estando presente Bernardo, arzobispo de Toledo" ${ }^{\prime 1}$. No sabemos el momento específico de esta ceremonia litúrgica pero es posible que se desarrollara en el otoño de ese año ${ }^{72}$, por tanto con los ecos muy presentes de la reciente toma de Jerusalén (15 de julio de 1099) ${ }^{73}$. Dado su ascendiente sobre Sahagún a partir de haber detentado el cargo abacial y desde su nuevo rol jerárquico, muy probablemente Bernardo protagonizara la ceremonia.

Aunque con frecuencia se ha asociado este acto litúrgico con la activación de los altares que envolverían los tres ábsides de factura románica cuyos restos aún pueden observarse ${ }^{74}$ a mi modo de ver más bien inauguró un poderoso bloque occidental anexado al templo prerrománico que, como he indicado, aún con intervenciones posteriores, fue sufragado por el rey Alfonso III y 
concluido en el entorno del año 900. La cimentación de ese este bloque fue encontrada en 1933 y aunque desde época moderna la estructura a la que pertenecía fue identificada como restos del templo prerrománico, entonces pudo verse que eran de claro perfil románico ${ }^{75}$. En 1997 definí la estructura como un bloque de tipo galilea cluniacense y como panteón de Alfonso VI. Más tarde indiqué su anexión entre 1080 y 1099 (periodo-marco más probable de construcción) a la preexistente iglesia de Alfonso III. Dos son los argumentos más determinantes para considerar esta opción: en primer lugar la misma crónica escrita por un monje de Sahagún hacia 1120, cuando hace referencia a la iglesia monástica de Alfonso III señala que "hizo edificar la iglesia como hasta ahora aparece" ${ }^{\text {76 }}$; en segundo, documentos posteriores permiten comprobar la longevidad de esta estructura prerrománica a lo largo del siglo XII ${ }^{77}$. De hecho no es sino hasta el 9 de enero de 1213 cuando se indica que las reliquias martiriales de Facundo y Primitivo fueron trasladadas de la iglesia vieja (veteri ecclesia) a la nueva (novam) momento que nos orienta sobre la inminencia de la desaparición de la longeva basílica de Alfonso III y de la pronta dedicación del nuevo templo que mantuvo en su extremo occidental el panteón de Alfonso $\mathrm{VI}^{78}$ asemejando en su topografía a San Isidoro de León (fig. 6). Dos años antes, el 21 de abril de 1211, se había realizado la propia dedicación de la catedral compostelana (arzobispo Muñiz): lejos quedaba el derribo de la primitiva ecclesiola del rey astur, acontecido en el curso del año 1112 (HC I, 78) ${ }^{79}$ (fig. 7).

Fig. 6. Planta hipotética de la iglesia románica de Sahagún con añadido de bloque occidental (J. L. Senra)

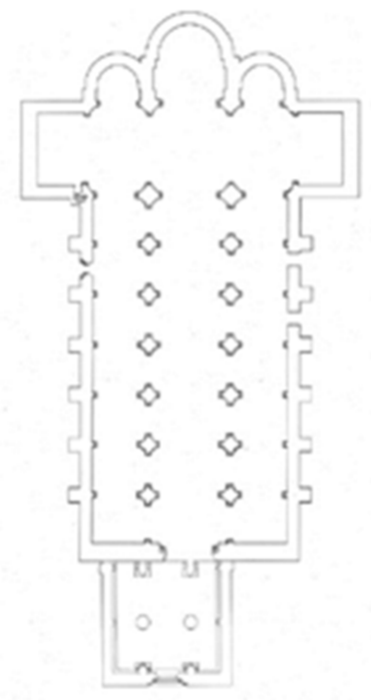


Fig. 7. Planta de la Catedral de Santiago (K. J. Conant)

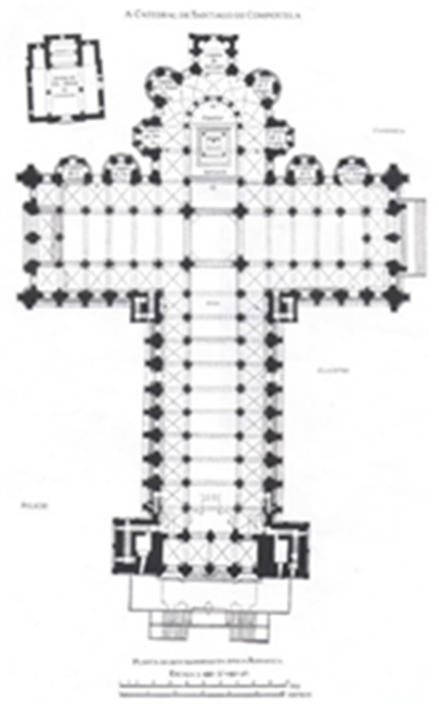

Es muy probable que el proyecto románico de una nueva iglesia en Sahagún fuera el resultado de la salida del monasterio de la profunda y agresiva crisis que experimentó con los desórdenes urbanos desarrollados entre 1110 y 1117. La desaparición del que fuera su valedor, el rey Alfonso VI, y la realidad de una iglesia prerrománica dañada después de los disturbios generan un clima propicio para considerar la sustitución: es significativo que en 1116 la reina Urraca emitiera el privilegio por el cual el monasterio podía emitir moneda incrementando su liquidez ${ }^{80}$. Tal logro había sido obtenido por Gelmírez en 1108 de un Alfonso VI en vísperas de su óbito, ad opus apostolice ecclesie ${ }^{81}$. Pero el proyecto asumido por los monjes estaba muy alejado del compostelano: si bien el avance de los trabajos fue igualmente muy quebrado, el modelo de templo adoptado asemejaba esclerótico en contraste al catedralicio, con una cabecera de tres ábsides abiertos a un pequeño transepto. Pero no solo ante la catedral, lo cual podría ser menos evidente dada la dimensión pública del santuario jacobeo, también frente a otras propuestas monásticas anteriores tanto peninsulares (Santa María de Ripoll o La Seo de Urgell por poner dos significativos ejemplos) como, de modo más contundente, del otro lado de los Pirineos. Resulta aún más elocuente respecto al caso de la abadía gascona de Saint-Sever a fines del siglo XI, ubicada en un territorio muy permeable a las relaciones institucionales del eje Pamplona-León ${ }^{82}$ (fig. 8). 
Fig. 8. Planta de la iglesia monástica de Saint-Sever (J. Cabanot)

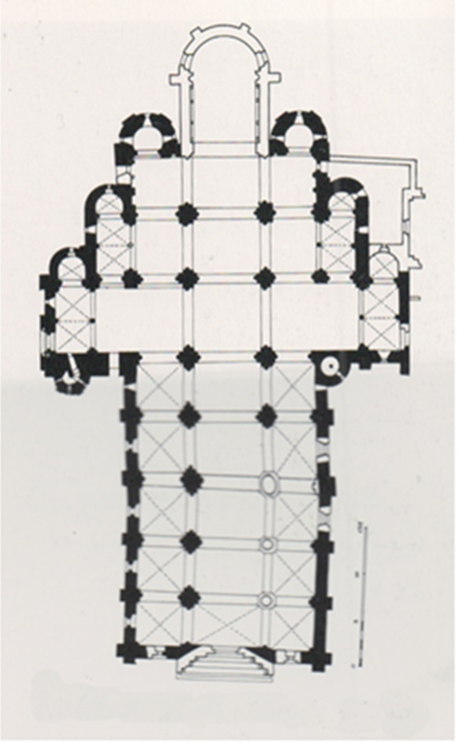

Con todo, a partir de sus proporciones, probablemente la compensación a este conservadurismo de planta se derivaría del alzado: la anchura de su cuerpo de naves superaba al de la catedral compostelana (23,5 metros frente a 19 de Santiago) con una nave central semejante ( 9 metros). Y desde la segunda mitad del siglo XII, con la obra aún no rematada, tanto en planta como en alzado probablemente ejerció, en mayor o menor medida, un papel arquetípico para los grandes edificios del Duero, área de influencia del monasterio -la Colegiata de Toro, la Catedral de Zamora y la Catedral de Salamanca, a los que superaba en tamaño. Quizá, aunque para ello carecemos de aval, incluso inspirando la singular tipología de cimborrios. Ya desde sus ruinas decimonónicas, el fervor del patriotismo krausista finisecular estimulado por el Diccionario de Viollet-le-Duc impulsó algún ejercicio de sesgo hagiográfico aplicado al templo sahguntino aludiendo a su precocidad y a sus presuntas consecuciones tectónicas superiores llegándose a considerar por encima de conjuntos franceses como la iglesia monástica de la Madeleine de Vézelay sobre la que volveremos en unas líneas ${ }^{83}$.

De regreso a la última década del siglo XI en Sahagún, el edificio resultante, constituido por dos unidades de construcción yuxtapuestos (iglesia y bloque occidental), se proyectaba fascinante en tanto, desde la semántica arquitectónica aunaba el mantenimiento de un pasado prestigioso y legitimador con un tiempo y unas formas nuevas ${ }^{84}$ (figs. 2 y 9). Pasado y futuro coexistían en una estructura arquitectónica sobre la que, andando el tiempo, se envolvió en una aura legendaria: concretamente hacia 1130 el LSI indicaba que la iglesia monástica de Sahagún -y este constituye un argumento complementario de refuerzo para establecer la amplia supervivencia de un edificio que rebasó con creces el siglo XI- fue mandada construir por Carlomagno. Sobre este particular retornaré más adelante. 
Fig. 9. Corte longitudinal de la iglesia financiada por Alfonso III con añadido de bloque occidental románico (J. L. Senra)
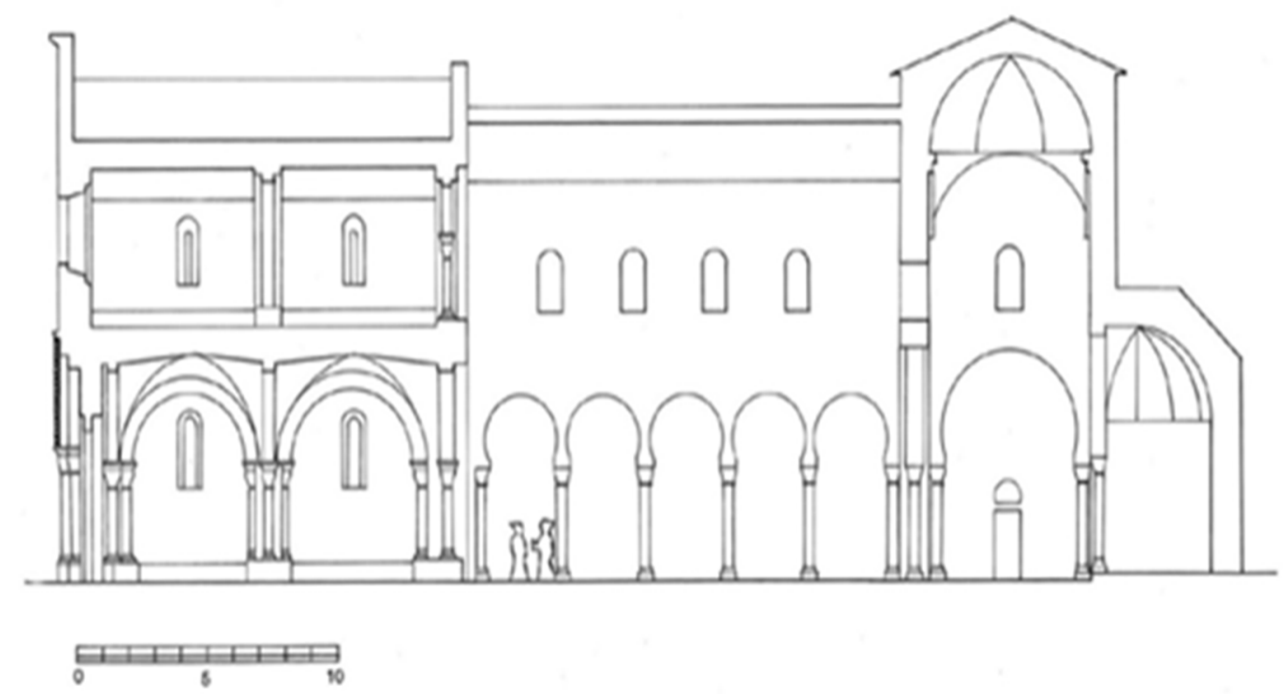

Poco sabemos de los elementos mueble del Sahagún de Alfonso VI. Si el testimonio de Ambrosio de Morales es veraz, el monarca habría sufragado un frontal de plata para el altar mayor de la iglesia de Sahagún "con figuras de santos de medio relieve". Dos referentes inevitables para su aproximación lo constituirían el Arca Santa de Oviedo (ca. ¿1090?) y el frontal de Diego Gelmírez en Compostela (1105). Sin embargo, el gran escollo es la dimensión que ofrece Morales, de unos 4,40 m. (16 pies castellanos), "el mayor que creo hay en España"85.

Lo cierto es que si hay algún resto arqueológico que permita asociar su construcción con ese mecenazgo real, como ya indiqué, tal fue la espaciosa galilea anexada al templo prerrománico ${ }^{86}$. Y dentro de ella, el elemento más destacado que se implementó para lo que en este trabajo me ocupa en las relaciones con Compostela, fue el umbral de separación con la iglesia prerrománica. Se trató de un triple acceso, rodada metáfora triunfal extendida en los arcos conmemorativos desde época romana e inyectada a partir del siglo IV en las basílicas cristianas con una significación rotundamente escatológica: el acceso al espacio eclesial en tanto prefiguración de la Jerusalén Celeste, es decir, la obtención de la vida eterna con referencia directa a los inhumados delante de ella (figs. 2 y 10). 
Fig. 10. Reconstrucción hipotética del acceso a la iglesia de Alfonso III en Sahagún desde el bloque occidental y panteón de Alfonso VI (J. L. Senra)

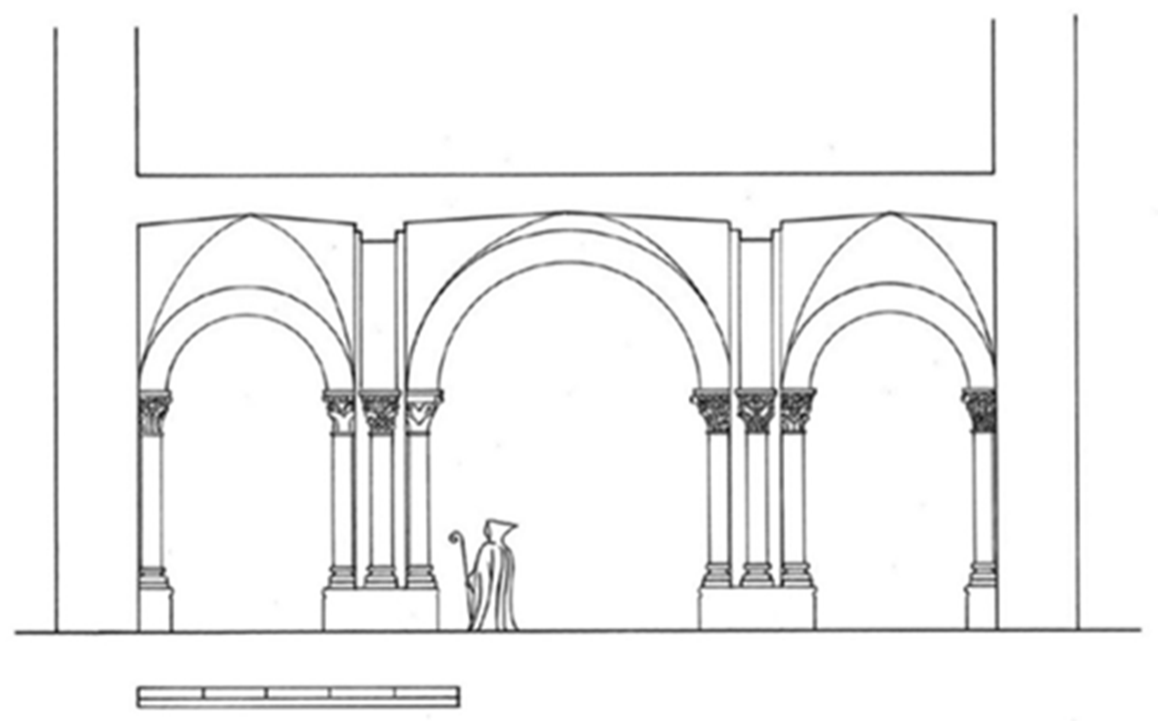

Impulsado desde los siglos VIII y IX por la arquitectura carolingia adquiere un singular desarrollo en el área borgoñona desde donde arraiga como un recurso frecuente. En los siglos X y XI aparece sujeta al tejido arquitectónico que separaba iglesia de bloque occidental: en esta dirección el ejemplo más significativo de los conservados es el de la iglesia del poderoso monasterio borgoñón de Saint-Philibert de Tournus (ca. 1030-1040) (Saône-et-Loire) (fig. 11). Más adelante, ya en la primera mitad del siglo XII, el procedimiento -de elevada asimilación en el territorio- se duplica introduciéndose también en el exterior de la fachada: en este sentido el templo también monástico de La Madeleine de Vézelay (Yonne) (ca. 1120-1130) supone la más excelsa materialización de esa concreción (fig. 12) ${ }^{87}$. 
Fig. 11. Planta de la iglesia monástica de Saint-Philibert de Tournus (J. Henriet)

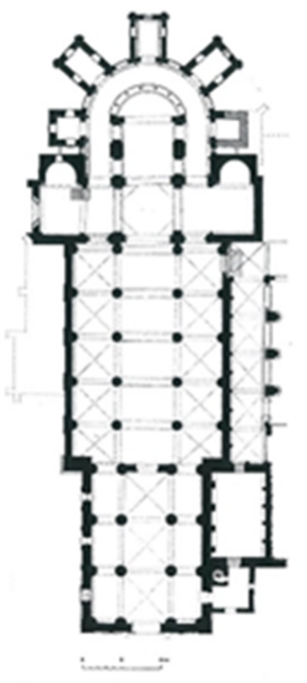

Fig. 12. Portada interior de la iglesia monástica de La Madeleine de Vézelay (Foto: J. L. Senra)

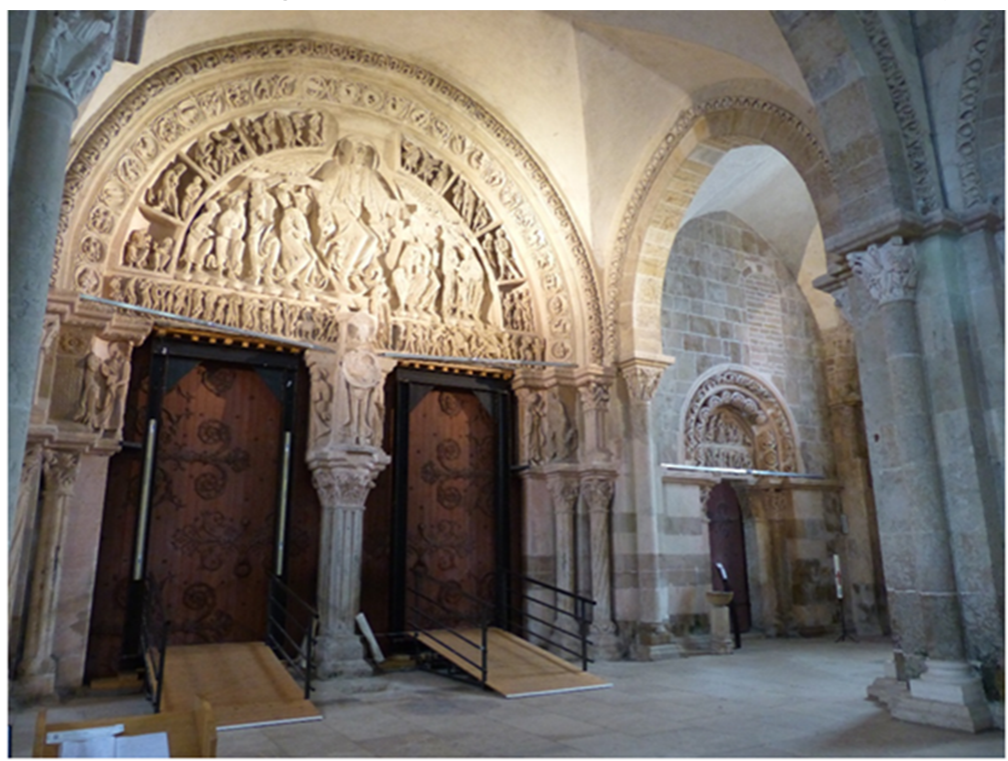

A partir de la presencia en León desde 1080 de Constanza de Borgoña, segunda esposa de Alfonso VI, es probable que la solución intermedia adoptada en Sahagún respondiera al modelo implantado en Tournus. Tanto la documentación previa a su matrimonio como la posterior son categóricas respecto a la sólida devoción de la futura reina a ese monasterio borgoñón, a poca distancia del que fuera su lugar de residencia, Chalon. Y la documentación localiza en León a dos monjes de aquella abadía en la década de los años ochenta. Que en Sahagún se adoptara esa solución a fines del siglo XI no es cuestión en absoluto menor en tanto no tenemos constancia de esa tiplología en templos peninsulares hasta que lo aplicara Mateo entre 1168-1088 en el extraordinario cierre occidental de la catedral compostelana (fig. 13). 
Fig. 13. Pórtico de la Gloria (J. Vilariño)

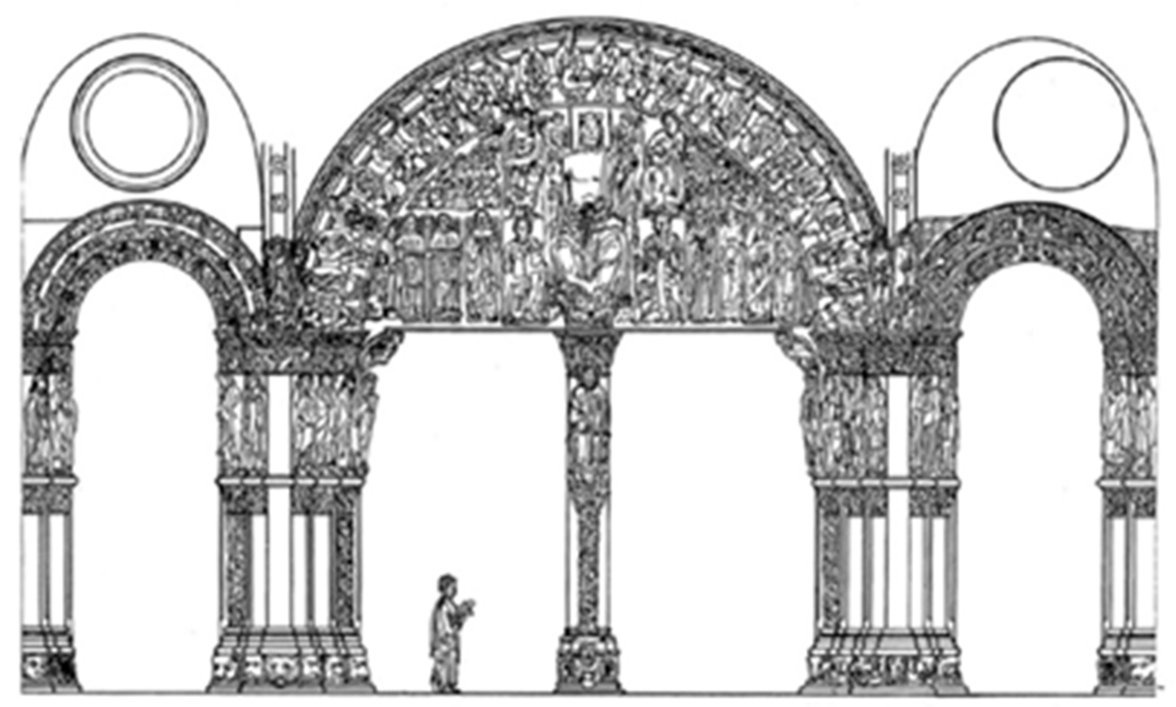

Obviamente sería ingenuo y simplista considerar que Sahagún condicionó la solución adoptada por Mateo que responde a un estadio más maduro y cuyo prototipo conceptual más elaborado y posterior en cronología ya ha sido mentado: Vézelay. Mateo, conocedor de esta tipología de pórtico de raíz monástico, le aplicó una compacidad envolvente de un elevado efectismo dramático. La inserción de una escultura masiva de diálogo vetero y neo testamentario 'obligaba' al espectador a sumergirse en una intensa experiencia performativa vitalizada por la liturgia de los canónigos. La solución elevó además su significación una vez que Mateo, tomando como módulo el triple acceso (interior y exterior) segmentó verticalmente el espacio también en tres niveles (cripta, pórtico y tribuna). En definitiva, distanciados por un centenar de años, los pórticos de Sahagún y de Compostela responden a dos generaciones diferentes pero de un mismo arquetipo tipológico.

Es preciso añadir un elemento significativo en la actividad constructiva del monasterio de Sahagún asociada a la catedral compostelana. Entre las acciones impulsadas por el matronazgo de la segunda de las esposas de Alfonso VI, Constanza, tenemos documentada la edificación, próxima al palacio, de una iglesia dedicada a la Magdalena, (ecclesiam Sancte Marie Magdalene) primera constatación de esa advocación en la península ${ }^{88}$. Y junto a ella la posesión de una reliquia del 'apóstol de los apóstoles', el dedo pulgar que, junto al Lignum Crucis, fue sustraído del monasterio por Alfonso I de Aragón en el marco de los desórdenes generados tras la muerte de Alfonso VI (1110-1117) ${ }^{89}$. La procedencia de la reliquia bien pudo haber estado asociada a la propia Constanza entre 1080 y1093, pero lo cierto es que en 1105 se consagró a la Magdalena, no sin manifiesta intencionalidad frente al del Salvador, el altar matutinal de la catedral compostelana ${ }^{90}$. Y hacia esas mismas fechas también se planificó un altar con esa misma dedicación en la nueva iglesia de San Zoilo de Carrión ${ }^{91}$. Pero Sahagún también conservaba otros restos apostólicos: una donación de Alfonso VI al monasterio datada en 1078, además de invocar a sus santos-mártires patronos, los hermanos Facundo y Primitivo, hace alusión a la presencia en la institución de reliquias de Santiago y Juan, también hermanos y con altares preferentes en la cabecera compostelana ${ }^{92}$. 
En la interrelación catedral y monasterio, un hecho de trascendencia en estos años fue el establecimiento del eje Sahagún-Toledo tras la toma en 1085 de la que fuera principal sede política visigoda, todo un impulso de prestigio identitario para las aspiraciones del monarca. Ya hice referencia a la elevación, solo un año después, del hasta entonces abad de Sahagún, Bernardo de La Sauvetat (1080-1086), al restituido arzobispado metropolitano. Es significativo que el mismo año de acceso al solio episcopal se concluyera en el scriptorium del monasterio leonés un Beato -el llamado Beato de Osma- con rasgos de estilo manifiestamente innovadores y en cuyo mapamundi se incluía con énfasis la representación conmemorativa tanto la sede toledana en forma de fortaleza como el santuario compostelano con la esfinge del apóstol ${ }^{93}$. De este modo se trazaba un triángulo de poder que no hacía sino elevar a la dimensión figurativa una incuestionable y poderosa realidad geopolítica $^{94}$.

\section{UN COLOFÓN LEGENDARIO: CARLOMAGNO EN COMPOSTELA Y SAHAGÚN}

La verdadera dimensión continental del culto jacobeo se obtuvo en el siglo XII y una de las piezas utilizadas para ello fue la instrumentalización de Carlomagno: su perfil guerrero era idóneo para hacerlo adalid de la Guerra Santa y su defensa de la Iglesia lo convertía en óptimo favorecedor de la devoción al apóstol Santiago. De este modo el libro cuarto del LSI, la llamada Historia Turpín (IV, 8), obra de hacia 1130 que circuló también de manera independiente a aquel, elevaba la dimensión hispana del emperador a través del tan recurrente medio del sueño: la misión de liberar la península del Islam le habría sido comunicada por el mismo apóstol Santiago ${ }^{95}$. Carlomagno habría peregrinado a Compostela y dotado con largueza su basílica; sin embargo aunque el autor no se atrevió a responsabilizarle de su construcción como había hecho con la de Sahagún, sí de la consagración del edificio y de su altar ${ }^{96}$. Y no deja de ser significativo que más allá de Compostela, el lugar de la ruta jacobea en la península que se destaca tanto en la Historia Turpin como en la globalidad del LSI sea precisamente Sahagún vinculado al iter hispanicum del emperador carolingio.

Ya el libro quinto del LSI, asimilando el contenido del tercero, reiteraba en dos pasajes el hito que suponía Sahagún en la ruta: "Igualmente se han de visitar los cuerpos de los santos mártires Facundo y Primitivo, cuya basílica levantó Carlomagno; y junto a la villa de éstos se encuentran los prados con arbolado en los que clavadas florecieron las astas de las lanzas de los guerreros, según se cuenta. Se celebra su solemnidad el 27 de noviembre"97. También se dice: "Después está Sahagún, pródigo en toda suerte de bienes, y en donde se encuentra el prado en el que, clavadas las resplandecientes lanzas de los victoriosos campeones de la gloria del Señor, se dice que florecieron" ${ }^{98}$. El relato legendario del libro tercero, de corte intensamente bélico-moralizante, envolvía a Sahagún en el aura de prestigio del emperador franco a partir de la derrota del enemigo islámico comandado por Agolant no sin dolorosas pérdidas entre sus tropas ${ }^{99}$. Sin embargo, a modo de recuerdo sacro, las lanzas de los milites christi carolingios que al día siguiente caerían en batalla habrían florecido generando un bosque, un alegato visual de impulso hacia la guerra santa y el sacrificio recompensado ${ }^{100}$. Es decir, la voluntad de lanzar una narrativa sobre la misión providencial de Carlomagno en la península ibérica respondía a la génesis de un referente poderoso para el impulso de la guerra santa contra el Islam ${ }^{101}$. 
En el germen de este escenario apócrifo hay una cuestión a tener presente. ¿Sobre qué mimbres se habría generado? ¿Habría algún substrato de apoyo? A lo largo de este trabajo se ha subrayado el potente eje Sahagún-Toledo establecido desde que Alfonso VI lanzó su campaña de conquista de la ciudad y por ende de su amplio dominio territorial. No es cuestión menor que el abad más carismático del monasterio leonés fuera nombrado arzobispo de la restaurada sede metropolitana. El valor de memoria y legitimación que llevaba consigo Toledo era superlativo y la repercusión en la cristiandad de su conquista elevó el prestigio de Alfonso como el de ningún otro monarca hispano hasta entonces. Más aún cuando la idea de una Cruzada a Tierra Santa comenzaba a tomar cuerpo. Habría que añadir una segunda pieza: el coste de mantener la ciudad bajo dominio cristiano no fue pequeño. La trágica batalla de Uclés (1108) acontecida para defenderla de un ataque almorávide y el clímax trágico resultante se incrementó aún más con el hecho de que en esta derrota murió también el joven heredero del reino así como los llamados siete condes, grandes magnates muy próximos al monarca.

Ya se ha hecho referencia a que esta narrativa histórica fuera un importante nutriente para el relato legendario de la Historia Turpin. Pero quizá no se haya hecho el necesario énfasis al enorme peso de la memoria que, a partir del afinado procedimiento litúrgico cluniacense, impulsó el monasterio acerca de las oraciones perpetuas dedicadas tanto al rey, a sus esposas allí enterradas como a los destacados caídos en la trágica batalla también inhumados en el monasterio. Aunque no es posible asegurarlo, el más probable lugar en el que reposaron estos últimos fue igualmente el bloque occidental inaugurado solo siete años antes, una verdadera arquitectura-memorándum anexa, como vimos, al viejo templo de Alfonso III $^{102}$. Es relevante que en fecha desconocida, en sus muros se dispusiera la representación de la batalla de Uclés ${ }^{103}$. El bloque constituía una verdadera proyección en tres dimensiones del necrologio monástico; un artefacto visual de recuerdo cíclico y perpetuo por parte de los monjes. En él, como antesala del Paraíso evocada por la triple puerta de acceso al templo anexo, se detenían las procesiones litúrgicas dominicales para orar por la salvación de los difuntos allí reunidos. Desde su rol de transmisor de la memoria colectiva a partir de su escenografía funeraria no puede dudarse de que, si el viejo templo prerrománico con su contenido martirial fue instrumentalizado en pro del relato de Carlomagno, el contenido de su bloque occidental, alentado por la comunidad de monjes, debió ejercer como estimulante para la fabricación de un relato mítico: un rey conquistador, un ejército comprometido en pro de la Iglesia y el imprescindible elemento trágico de la pérdida de la vida en una causa santa como era la guerra contra el no creyente. Parece probable que el relato de la Historia Turpin se nutriera del substrato creado por esa sólida y fértil unión umbilical entre Compostela, Sahagún y Toledo con el trascendente recuerdo de la batalla de Uclés.

Por otro lado, este relato llevaba consigo una atractiva carga moralizante impulsada desde el paisaje próximo al monasterio: la arboleda se convertía en trasunto alegórico del armamento de una batalla que adquiría la categoría de universal y escatológica: el perpetuo combate entre virtudes y vicios a modo de psychomachia. Según la Historia Turpin, al igual que las tropas carolingias combatieron al enemigo islámico, los fieles debían afanarse en su lucha contra las tentaciones lanzadas por el diablo. De este modo en Sahagún y su entorno se instaló un relato con un doble pasado martirial: el autóctono a partir de sus patronos hispanorromanos y el foráneo con los mártires-soldados caídos en batalla contra el infiel a su vez solapado con los magnates alfonsinos caídos. Una yuxtaposición de hagiografías local y foránea circunstancialmente alojada en un edificio igualmente dual en su morfología ${ }^{104}$. Nunca sabremos el exacto modo en que coexistieron estos 
contrapuestos relatos desde el siglo XII; en cualquier caso el autor de la HLS (ca. 1120), del que ya menté su muy convincente pertenencia al monasterio de Sahagún, proclamaba no mucho antes de que la Historia Turpin fuera redactada, las pretensiones apócrifas orales que hiperbolizaban la presencia y acciones de Carlomagno en la península guerreando contra el Islam ${ }^{105}$. Alimento legendario para los peregrinos que, con las resonancias del doble relato-epopeya, caminaban hacia el santuario jacobeo uniendo, en un iter de ida y vuelta, dos de las más importantes instituciones de la Iberia medieval.

\section{REFERENCIAS}

Adámková, Iva. "Qualche considerazione sulla posa delle pietre nelle fondamenta degli edifici sacrali nel Medioevo." Folia philologica 131 (2008): 29-44.

Agúndez San Miguel, Leticia. La memoria escrita en el monasterio de Sahagún (años 904-1300), 238-290. Madrid: CSIC, 2019.

Alexander, Jennifer y Martin, Therese. "Sistemas constructivos en las fases iniciales de la Catedral de Santiago: una nueva mirada al edificio románico a través de las marcas de cantería." In En el principio. Génesis de la Catedral Románica de Santiago de Compostela. Contexto, construcción y programa iconográfico (J. L. Senra, ed.), 142-163. Santiago de Compostela: Teófilo Edicions, 2014.

Andrade Cernadas, José Miguel. "El episcopado iriense del primer Diego: contexto, fuentes y perfil biográfico." In En el principio: Génesis de la Catedral Románica de Santiago de Compostela. Contexto, construcción y programa iconográfico (J. L. Senra, ed.), 10-29. Santiago de Compostela: Teófilo Edicions, 2014.

Andrade Cernadas, José Miguel. "La Concordia de Antealtares en su contexto histórico." In Los reyes de Asturias y los orígenes del culto a la tumba del apóstol Santiago (F. J. Fernández Conde; R. Alonso Álvarez, eds.), 109-126. Gijón: Ediciones Trea, 2017.

Beda el Venerable. “De templo Salomonis." In Patrologia Latina (J. P. Migne, ed.), vol. XCI, col. 735-808, esp. 744-746. París, 1862.

Bünz, Enno. "lapis angularis`- Die Grunstein-legung 1010 als Schlüssel für den mittelalterlichen Kirchenbau von St. Michael in Hildesheim." In 1000 Jahre St. Michael in Hildesheim. Kirche-Kloster-Stifter (G. Lutz / A. Weyer, ed.), 77-87. Petersberg: Verlag, 2021.

Carrero, Eduardo. "El altar mayor y el altar matinal en el presbiterio de la Catedral de Santiago de Compostela. La instalación litúrgica para el culto a un apóstol," Territorio y Sociedad 8 (2013): 19-52.

Carrero Santamaría, Eduardo. "Oviedo y Compostela: conmemoración litúrgica, arquitectura y conjuntos de iglesias en la Alta Edad Media peninsular." In Los reyes de Asturias y los orígenes del culto a la tumba del apóstol Santiago (F. J. Fernández Conde / R. Alonso Álvarez, eds.), 93-108. Gijón: Ediciones Trea, 2017.

Castiñeiras González, Manuel A. "La catedral medieval: la dilatada historia de la obra románica y su epílogo medieval." In La Catedral de los Caminos. Estudios sobre Arte e Historia, 241-383. Santiago de Compostela: Fundación Catedral de Santiago, 2020.

Cartron, Isabelle. Les pérégrinations de Saint-Philibert. Genèse d'un réseau monastique dans la societé carolingienne. Rennes: Presses Universitaires de Rennes, 2009. https://doi.org/10.4000/books.pur.1 $\underline{26219}$

Chapapría Julian Esteban y García Cuetos, María Pilar. Alejandro Ferrant y la conservación monumental en España (1929-1939). Castilla y León y la Primera Zona Monumental. Valladolid: Junta de Castilla, 2007, 2 vols. 
Cosmen Alonso, Concepción; Herráez Ortega, María Victoria; Valdés Fernández, Manuel. "Alfonso VI y el monasterio de Sahagún. Nuevos testimonios sobre la construcción del templo monástico." De Arte 5 (2006): 29-41. https://doi.org/10.18002/da.v0i5.1544

Díaz de Bustamante, José Manuel y López Pereira, José Eduardo. “El Acta de Consagración de la catedral de Santiago. Edición y estudios crítico." Compostellanum 35 (1990): 377-400.

Díaz y Díaz, Manuel C. El Códice Calixtino de la Catedral de Santiago. Estudio codicológico y de contenido. Santiago de Compostela: Centro de Estudios Jacobeos, 1998.

Dinter, Peter (ed.) Liber Tramitis aevi Odilonis Abbatis. Siegburg: Franz Schmitt, 1980.

Falque Rey, Emma (ed.) Historia Compostelana. Madrid: Akal, 1994.

Ferotin, Marius. "Une lettre inédite de Saint Hugues abbé de Cluny à Bernard d'Agen, archevêque de Tolède (1087)." Bibliotheque de l'École des Chartes LXI (1900): 339-345.

Ferotin, Marius. "Complément de la lettre de Saint Hugues, abbé de Cluny à Bernard d’Agen, archevêque de Tolède (1087).” Bibliotheque de l'École des Chartes LXIII (1902): 1-5. https://doi.org/10.3406/bec.19 $\underline{02.448122}$

Fernández Catón, José María. "Datos para la historia del martirio y del culto de las reliquias de los mártires leoneses Facundo y Primitivo.” In Bivium. Homenaje a Manuel Cecilio Díazy Díaz, 67-79. Madrid: Gredos, 1983.

Gambra, Andrés. Alfonso VI. Cancillería, curia e imperio. León: Centro de Estudios e Investigación 'San Isidoro', 1997, 2 vols.

García, Charles. El espacio, el tiempo y lo maravilloso en el reino de León (sS. XI-XIII). Representaciones ideales y comportamientos sociales, 235-259. Madrid: La Ergástula, 2018.

García Iglesias, José Manuel. “Espacios y percepciones. María Magdalena en la Catedral de Santiago de Compostela." Quintana 2 (2003): 41-56

García de Castro Valdés, César y Valdés Gallego, José Antonio. "Las inscripciones perdidas de la basílica altomedieval de San Salvador de Oviedo." Espacio, Tiempo y Forma. Historia Medieval 33 (2020): 223-270. https://doi.org/10.5944/etfiii.33.2020.26141

García Rodríguez, Carmen. El culto a los santos en la España romana y visigoda. Madrid: Consejo Superior de Investigaciones Científicas, 1966.

Gil Fernández, Juan / Moralejo, José Luis / Ruiz de la Peña, Juan Ignacio, ed.). “Crónica Albeldense.” In Crónicas asturianas. Oviedo: Universidad de Oviedo, 1985.

Gómez Moreno, Manuel. Introducción a la Historia Silense. Madrid: Centro de Estudios Históricos, 1921.

Guerra Campos, José. Exploraciones arqueológicas en torno al sepulcro del Apóstol Santiago. Santiago de Compostela: Cabildo Catedral de Santiago, 1982.

Guardiola, Juan Benito. Historia del Monasterio de San Benito el Real de Sahagún (según el Ms. 1519 de la BN) (H. S. Martínez, ed.) León: Universidad de León, 2007.

Harris, Julie. "Mosque to Church Conversions in the Spanish Reconquest". Medieval Encounters 3/2 (1997): 158-172. https://doi.org/10.1163/157006797X00116

Hebers, Klaus. "El Códice Calixtino, el libro de la Iglesia compostelana." In Compostela y Europa: la historia de Diego Gelmírez (M. Castiñeiras González, dir.), 122-141. Milán: Skira, 2010.

Henriet, Patrick. “"Capitale de toute vie monastique», «élevée entre toutes les églises d'Espagne». Cluny et Saint-Jacques au XII. siècle." In Saint-Jacques et la France (Actes du Colloque des 18 et 19 janvier 2001 à la Fondation Singer-Polignac y A. Rucquoi, dir.), 407-449. París: Les Éditions du Cerf, 2003. 
Henriet, Patrick. "L'Historia Silensis, chronique écrite par un moine de Sahagún. Nouveaux arguments", eSpania [En ligne], 14 | décembre 2012, mis en ligne le 05 janvier 2013, consulté le 19 juin 2021. URL : http://journals.openedition.org/e-spania/21655 ; https://doi.org/10.4000/e-spania.21655

Herráez Ortega, María Victoria (coord.) Esplendor y decadencia de un monasterio medieval. El patrimonio artístico de San Benito de Sahagún, 62-64. León: Ediciones Universidad de León, 2000.

Herrero de la Fuente, Marta. Colección diplomática del monasterio de Sahagún, 1110-1199. IV. 1110-1199, León: Centro de Estudios e Investigación 'San Isidoro',1988.

Herrero de la Fuente, Marta. "De Cluny a Sahagún: la escritura carolina en el monasterio de Sahagún (siglos XI-XII)." In Le statut du scripteur au Moyen Age (Actes du XII ${ }^{\mathrm{e}}$. colloque scientifique du Comité International de Paléographie Latine, Cluny, 17-20 juillet 1998 / M.-C. Hubert, E. Poulle, M. H. Smith, coords.), 29-40. París: École des Chartes, 2000.

Hopper, Vincent F. La symbolique médiévale des nombres. París: Gérard Momfort, 1995 (Nueva York, 1938).

Iogna-Prat, Dominique. La Maison de Dieu. Une histoire monumentale de l'Eglise au Moyen Âge. París: Éditions du Seuil, 2006. https://doi.org/10.14375/NP.9782020862578

Isla Frez, Amancio. Memoria, culto y monarquía hispánica entre los siglos XI y XII, 180. Jaén: Universidad de Jaén, 2006.

Kazhdan, Alexander P. “ «Constantin Imaginaire». Byzantine Legends of the Ninth Century about Constantine the Great." Byzantion 57 (1987): 196-250.

Kohnle, Armin. AbtHugo von Cluny (1049-1109). Sigmaringen: Verlag, 1993.

Klápště, Jan. The Czech Lands in Medieval Transformation. Leiden: Brill, 2012. https://doi.org/10.1163/97 89004226463

Ladner, Gerhart B. "The Symbolism of the Biblical Corner Stone in the Mediaeval West." In Images and Ideas in the Middle Ages. Selected Studies in History and Art, vol. I, 171-196. Roma: Edizioni di Storia e Letteratura, 1983.

López Alsina, Fernando. La ciudad de Santiago de Compostela en la Alta Edad Media. Santiago de Compostela: Centro de Estudios Jacobeos, 1988.

López Martínez-Morás, Santiago. Épica y Camino de Santiago. En torno al Pseudo Turpín. A Coruña: Seminario de Estudos Galegos, 2002.

Löw, Martina. "The Constitution of Spaces Through the Simultaneity of Effect and Perception." European Journal of Social Theory 11/1 (2008): 25-49. https://doi.org/10.1177/1368431007085286

Maines, Clark. "The Charlemagne Window at Chartres: New Considerations on Text and Image." Speculum 52 (1977): 801-823. https://doi.org/10.2307/2855375

Martínez, H. Salvador. "Leyendas épicas carolingias en la ruta jacobea. Milón de Angleris en Sahagún." Argutorio 31 (2013): 42-53.

Mínguez Fernández, José María. El dominio del monasterio de Sahagún el en siglo X. Salamanca: Ediciones Universidad de Salamanca, 1980.

Molina Figueras, Joan. "Arnau de Montrodon y la Catedral de San Carlomagno. Sobre la imagen y el culto al emperador carolingio en Gerona." Anuario de Estudios Medievales 34 (2004): 417-454. https://doi.or g/10.3989/aem.2004.v34.i1.190

Moore, Kathryn Blair. The Architecture of the Christian Holy Land. Reception from Late Antiquity through the Renaissance. Cambridge: Cambridge University Press, 2017. https://doi.org/10.1017/978131648836 $\underline{2}$

Moralejo, Abelardo; Torres, Casimiro; Feo, Julio, ed.), Liber Sancti Jacobi. 'Codex Calixtinus'. Santiago de Compostela: Xunta de Galicia, 1992 (1951). 
Moralejo, Serafín. "Notas para una revisión de la obra de K. J. Conant." In Kenneth John Conant, Arquitectura Románica da Catedral de Santiago de Compostela, 221-236. Santiago de Compostela: Colexio de Arquitectos de Galicia, 1983.

Moralejo, Serafín. “Santiago de Compostela: la instauración de un taller románico." In Talleres de arquitectura en la Edad Media, 127-144. Barcelona: Moleiro, 1995.

Moralejo, Serafín. "El mundo y el tiempo en el mapa del beato de Osma." In Patrimonio artístico de Galicia y otros estudios. Homenaje al profesor Serafín Moralejo Álvarez (A. Franco Mata / E. Romero Pose, ed.), tomo II, 237-260. Santiago de Compostela: Xunta de Galicia, 2004.

Morales, Ambrosio de. Viage por orden del rey D. Felipe II a los reinos de León, Galicia y Principado de Asturias para reconocer las reliquias de los santos. Madrid: Antonio Marín, 1765.

Mostert, Marco. The Political Theology of Abbo of Fleury. A Study of the Ideas about Society and Law of the Tenth-Century Monastic Reform Movement, 24-26. Hilversum: Verloren Publishers, 1987.

Noble, Thomas F. X. Images, Iconoclasm, and the Carolingians. Philadelphia: University of Pennsylvania Press, 2009. https://doi.org/10.9783/9780812202960

Ohly, Friedrich. "Vom geistigen Sinn des Wortes im Mittelalter." Zeitschrift für deutsches Alternum und deutsche Literatur 89 (1958): 1-23.

Portela Silva, Ermelindo. “La Catedral en la Historia. De los orígenes a la reforma. Siglos IX-XV." In La Catedral de los Caminos. Estudios sobre Arte e Historia, 9-82. Santiago de Compostela: Fundación Catedral de Santiago, 2020.

Rabe, Susan A. Faith, Art and Politics at Saint-Riquier. The Symbolic Vision of Angilbert. University Pennsylvania Press, 2017.

Reglero de la Fuente, Carlos M. "La primera reforma cluniacense de Sahagún, el Concilio de Burgos y la crisis de 1080: revisión cronológica y desarrollo.” In Monarquía y sociedad en el reino de León. De Alfonso III a Alfonso VII (J. M. Fernández Catón, ed.), vol. II, 689-732. León: Centro de Estudios e Investigación San Isidoro, 2007.

Reglero de la Fuente, Carlos M. Cluny en España. Los prioratos de la provincia y sus redes sociales (1073ca.1270). León: Centro de Estudios e Investigación San Isidoro, 2008. https://doi.org/10.4000/cem.1 1145

Reilly, Bernard F. El reino de León y Castilla bajo el rey Alfonso VI, 1065-1109. Toledo: Instituto Provincial de Investigaciones y Estudios Toledanos, 1989 (Princeton, 1987).

Remensnyder, Amy G. Remembering Kings Past: Monastici Foundation Legends in Medieval Southern France. Ithaca: Cornell University Press, 1995.

Rico, Francisco, Las letras latinas del siglo XII en Galicia, León y Castilla, 76-81. Madrid: Castalia, 1969.

Riesco Chueca, P. (ed.) Pasionario hispánico. Sevilla: Universidad-Secretariado de Publicaciones, 1995.

Rubio Sadia, Juan Pablo. Las órdenes religiosas y la introducción del rito romano en la Iglesia de Toledo. Una aportación desde las fuentes litúrgicas, 51-68. Toledo: Instituto Teológico San Ildefonso, 2004.

Ruiz Albi, Irene. La reina doña Urraca (1109-1126). Cancillería y colección diplomática. León: Centro de Estudios e Investigación San Isidoro, 2003.

S. A. “Lápida monumental de Sahagún." Boletín de la Real Academia de la Historia 28 (1896): 94-96.

Senra, José Luis. "Peregrinaciones y reliquias en las rutas hacia Compostela. Héroes y santos a la vera del Camino." Memoria Ecclesiae 18 (2001): 277-292.

Senra, José Luis. "En torno a un espacio de evocación: las Res Gesta Domini Adefonsi y la iglesia monástica de Sahagún." In La construcción medieval de la memoria regia (P. Martínez Sopena / Ana Rodríguez, eds.), 243-292. Valencia: Universitat de Valencia, 2011. 
Senra, José Luis: "Tournus et Sahagún: une connexion architecturale et institutionnelle à la fin du XI. siècle?" Bulletin du centre d'études médiévales d'Auxerre (BUCEMA) 15/1, (2011): 267-281. https://doi.org/1 $\underline{0.4000 / \text { cem. } 12103}$

Senra, José Luis. “Concepto filiación y talleres del primer proyecto catedralicio." In En el principio. Génesis de la Catedral Románica de Santiago de Compostela. Contexto, construcción y programa iconográfico (J. L. Senra, ed.), 58-141. Santiago de Compostela: Teófilo Edicions, 2014.

Senra, José Luis. "La iconografía del primer proyecto catedralicio: un tránsito de perfección hacia el hombre espiritual," 164-201. In En el principio. Génesis de la Catedral Románica de Santiago de Compostela. Contexto, construcción y programa iconográfico (J. L. Senra, ed.), 58-141. Santiago de Compostela: Teófilo Edicions, 2014.

Senra, José Luis. "Reflexiones en torno a los principios y fundamentos de la catedral románica de Santiago de Compostela (ca. 1075-1105)." Revista Chilena de Estudios Medievales 10 (2016): 9-46.

Senra, José Luis. "«May the Angels Lead You into Paradise»: Staging the Cluniac Liturgy in Medieval Hispanic priories." Journal of Medieval Iberian Studies 9 (2017): 149-183. https://doi.org/10.1080/17546559. $\underline{2017.1342853}$

Serrano, Luciano. Cartulario de San Pedro de Arlanza. Madrid: Centro de Estudios Históricos, 1925.

Shailor, Barbara A. "The Scriptorium of San Sahagún: A Period of Transition." In Santiago, Saint-Denis, and Saint Peter: the reception of the Roman liturgy in Leon-Castile in 1080, 41-61. Nueva York: Fordham University Press, 1985.

Solar, José. "La antigua iglesia del monasterio de Sahagún y sus bóvedas botareles." Boletín de la Institución Libre de Enseñanza 180 (1884): 232-233.

Solar, José. "Algunos rasgos de la iglesia grande del monasterio de Sahagún." Boletín de la Institución Libre de Enseñanza 201 (1885): 184-185.

Thunø, Erik. The Apse Mosaic in Early Medieval Rome. Time, Network, and Repetitio. Cambridge: Cambridge University Press, 2015. https://doi.org/10.1017/CB09781107707078

Ubieto Arteta, Antonio (ed.). Crónicas anónimas de Sahagún. Zaragoza: Anubar Ediciones, 1986.

Vergnolle, Eliane. L'art roman en France. París: Flammarion, 1994.

Williams, John. The Illustrated Beatus. A Corpus of the Illustrations of the Commentary on the Apocalypse. The Eleventh and Twelfth Centuries. Londres: Harvey Miller Publishers, 2002.

Wulf, Christine. "Inschriftenkatalog: Stadt Hildesheim. Katalogartikel in Chronologischer Reihenfolge DI 58: Satadt Hildesheim, no 6 (2003).

Notas

$1 \quad$ Este trabajo se enmarca en el Proyecto Nacional de Investigación Espacio, letra e imagen: la Iberia medieval y el impacto de Cluny en el arte, la arquitectura y la liturgia (Ref. RTI2018-098972-B-100) financiado por el Ministerio de Ciencia, Innovación y Universidades. Gobierno de España.

2 Löw, Martina. "The Constitution of Spaces Through the Simultaneity of Effect and Perception." European Journal of Social Theory 11/1 (2008): 25-49.

3 Ubieto Arteta, Antonio (ed.). “Primera Crónica de Sahagún.” In Crónicas anónimas de Sahagún. Zaragoza: Anubar Ediciones, 1986. A partir de su supervivencia como una traducción del latín al romance, la Primera Crónica de Sahagún ha sido sometida a análisis recientes en los que se ha llegado a poner en duda su autenticidad entendiéndola como un producto manipulado en la Baja Edad Media. Aunque no es este el lugar para explayarse sobre algunos de los argumentos expuestos, en mi opinión, es obvio que una traducción de la segunda mitad del siglo XV no puede comprenderse desde el purismo metodológico contemporáneo por lo que determinados giros, expresiones o incluso, de modo puntual, contenidos, pudieran haber sido mejorados sin que ello implique 
en absoluto su devaluación de la crónica como fuente documental de primer orden. Ver: García, Charles. El espacio, el tiempo y lo maravilloso en el reino de León (sS. XI-XIII). Representaciones ideales y comportamientos sociales, 235-259. Madrid: La Ergástula, 2018; Agúndez San Miguel, Leticia. La memoria escrita en el monasterio de Sahagún (años 904-1300), 238-290. Madrid: CSIC, 2019.

En función se su contenido categóricamente leonés desde el siglo pasado se ha desechado su vínculo a Silos (Historia Silense) tendiendo a denominarla Historia Legionense. Se hace uso terminológico de seminense a partir de la lógica propuesta de Francisco Rico a partir de la locución del autor de la crónica, eminentemente leonesa, al referirse al lugar desde el que la escribió, la domus seminis. Ver: Rico, Francisco, Las letras latinas del siglo XII en Galicia, León y Castilla, 76-81. Madrid: Castalia, 1969.

Sobre la hipótesis de la Historia Legionense redactada en Sahagún ver: Henriet, Patrick. "L'Historia Silensis, chronique écrite par un moine de Sahagún. Nouveaux arguments", e-Spania [En ligne], 14 | décembre 2012, mis en ligne le 05 janvier 2013, consulté le 19 juin 2021. URL : http://journals.openedition.org/e-spania/21655 ; DOI : https://doi.org/10.4000/e-spania.21655

6 Rubio Sadia, Juan Pablo. Las órdenes religiosas y la introducción del rito romano en la Iglesia de Toledo. Una aportación desde las fuentes litúrgicas, 51-68. Toledo: Instituto Teológico San Ildefonso, 2004.

7 Moralejo, Abelardo; Torres, Casimiro; Feo, Julio, ed.) Liber Sancti Jacobi. 'Codex Calixtinus', 573. Santiago de Compostela: Xunta de Galicia, 1992 (1951).

8 Herrero de la Fuente, Marta. Colección diplomática del monasterio de Sahagún, 1110-1199. IV. 1110-1199, doc. 1125. León: Centro de Estudios e Investigación ‘San Isidoro', 1988.

9 Un diploma de 1175 nos informa de que Silos y Arlanza contaban con 46 y 44 monjes respectivamente (Serrano, Luciano. Cartulario de San Pedro de Arlanza, doc. CXXIII, 225-227. Madrid: Centro de Estudios Históricos, 1925).

10 García Rodríguez, Carmen. El culto a los santos en la España romana y visigoda, 245-246. Madrid: Consejo Superior de Investigaciones Científicas, 1966. También: Pasionario hispánico (P. Riesco Chueca, ed.), 20-39. Sevilla: Universidad-Secretariado de Publicaciones, 1995.

11 “Crónica Albeldense.” (XV, 75-78) 180 y 254. In Crónicas asturianas (J. Gil Fernández / J. L. Moralejo / J. I. Ruiz de la Peña, ed.). Oviedo: Universidad de Oviedo, 1985.

12 Gómez Moreno, Manuel. Introducción a la Historia Silense, XCI. Madrid: Centro de Estudios Históricos, 1921.

13 En los años setenta del siglo XIX se asociaron restos de cenizas encontrados en las excavaciones de la catedral con la destrucción de al-Mansur; fueron verificados en los años cincuenta del siglo pasado (cit.: Guerra Campos, José. Exploraciones arqueológicas en torno al sepulcro del Apóstol Santiago, 365-368. Santiago de Compostela: Cabildo Catedral de Santiago, 1982). Por su parte, en 1814 la comunidad de Sahagún reconstruía la iglesia abacial después del erosivo paso de las tropas francesas poniendo el proceso en parangón con el ataque islámico de fines del siglo X a través de una lápida monumental ("Lápida monumental de Sahagún." Boletín de la Real Academia de la Historia 28 (1896): 94-96).

14 Ver recientemente: Carrero Santamaría, Eduardo. "Oviedo y Compostela: conmemoración litúrgica, arquitectura y conjuntos de iglesias en la Alta Edad Media peninsular." In Los reyes de Asturias y los orígenes del culto a la tumba del apóstol Santiago (F. J. Fernández Conde / R. Alonso Álvarez, eds.), 93-108. Gijón: Ediciones Trea, 2017.

15 Gómez Moreno, Historia Silense, XCI.

16 La utilización de material de acarreo desde Braga permite calibrar la importancia con la que se quiso dignificar el nuevo edificio. Sobre el acta: Díaz de Bustamante, José Manuel y López Pereira, José Eduardo. "El Acta de Consagración de la catedral de Santiago. Edición y estudios crítico." Compostellanum 35 (1990):377-400. Para este contexto ver recientemente: Portela Silva, Ermelindo. "La Catedral en la Historia. De los orígenes a la reforma. Siglos IX-XV." In La Catedral de los Caminos. Estudios sobre Arte e Historia, 9-82, esp. 24-33. Santiago de Compostela: Fundación Catedral de Santiago, 2020.

17 Mínguez Fernández, José María. El dominio del monasterio de Sahagún el en siglo X, 223-244. Salamanca: Ediciones Universidad de Salamanca, 1980.

18 Esta retórica de raíz clásica fue constante en la documentación de los siglos X y XI. Ver: Senra, José Luis. "En torno a un espacio de evocación: las Res Gesta Domini Adefonsi y la iglesia monástica de Sahagún." In La construcción medieval de la memoria regia (P. Martínez Sopena / Ana Rodríguez, eds.), 261, n. 58. Valencia: Universitat de Valencia, 2011.

19 Senra, "En torno a un espacio de evocación," 290-291.

20 Senra, "En torno a un espacio de evocación," 261-262. 
Además de las iniciativas edilicias de Alfonso III subraya las impulsadas por Alfonso II y Ordoño II (Gómez Moreno, Historia Silense, $\mathrm{XCI}-\mathrm{XCII}$ ). Senra, "En torno a un espacio de evocación," 264.

Henriet, Patrick. “"Capitale de toute vie monastique», «élevée entre toutes les églises d'Espagne». Cluny et Saint-Jacques au XII ${ }^{\mathrm{e}}$ siècle." In Saint-Jacques et la France (Actes du Colloque des 18 et 19 janvier 2001 à la Fondation Singer-Polignac y A. Rucquoi, dir.), 407-449. París: Les Éditions du Cerf, 2003.

24 Sobre Dalmacio ver también: Gambra, Andrés. Alfonso VI. Cancillería, curia e imperio. I. Estudio, 642. León: Centro de Estudios e Investigación 'San Isidoro', 1997; Henriet, “"Capitale de toute vie monastique»," 430-432; Reglero de la Fuente, Carlos M. Cluny en España. Los prioratos de la provincia y sus redes sociales (1073-ca.1270), 347-348. León: Centro de Estudios e Investigación San Isidoro, 2008.

25 Reglero de la Fuente, Carlos M. "La primera reforma cluniacense de Sahagún, el Concilio de Burgos y la crisis de 1080: revisión cronológica y desarrollo.” In Monarquía y sociedad en el reino de León. De Alfonso III a Alfonso VII (J. M. Fernández Catón, ed.), vol. II, 689-732. León: Centro de Estudios e Investigación San Isidoro, 2007. Herrero de la Fuente, Colección diplomática de Sahagún (857-1230). III. 1073-1109, doc. 786, 76-79.

En este sentido es elocuente la irrupción de nuevas formas gráficas: la letra hispánica se ve desplazada de manera rotunda respecto a la carolina: el $44 \%$ de los diplomas conservados de la década de los años ochenta del siglo XI presentan esta última grafía; una década más tarde son ya el 67\%; en 1104 la totalidad responden ya a la forma carolina. Ver: Herrero de la Fuente, Marta. "De Cluny a Sahagún: la escritura carolina en el monasterio de Sahagún (siglos XI-XII).” In Le statut du scripteur au Moyen Age (Actes du XII colloque scientifique du Comité International de Paléographie Latine, Cluny, 17-20 juillet 1998 / M.-C. Hubert, E. Poulle, M. H. Smith, coords.), 29-40, esp. 33-34. París: École des Chartes, 2000. También: Shailor, Barbara A. "The Scriptorium of San Sahagún: A Period of Transition." In Santiago, Saint-Denis, and Saint Peter: the reception of the Roman liturgy in LeonCastile in 1080, 41-61. Nueva York: Fordham University Press, 1985.

28 Según las directrices de la abadía de Cluny: "luxta galileam constructum debet esse palatium" (Liber Tramitis aevi Odilonis Abbatis (P. Dinter, ed.), 205. Siegburg: Franz Schmitt, 1980).

29 La trascendencia del privilegio se pone de relieve por la ratificación del diploma: trece obispos y grandes magnates laicos (Reilly, Bernard F. El reino de León y Castilla bajo el rey Alfonso VI, 1065-1109, 131-132. Toledo: Instituto Provincial de Investigaciones y Estudios Toledanos, 1989 (Princeton, 1987).

Para explicar la caída en desgracia del obispo Peláez en 1088 se han argumentado las implicaciones derivadas de la restauración del arzobispado de Toledo dos años antes (Andrade, José M. "El episcopado iriense del primer Diego: contexto, fuentes y perfil biográfico.” In En el principio: Génesis de la Catedral Románica de Santiago de Compostela. Contexto, construcción y programa iconográfico (J. L. Senra, ed.), 10-29. Santiago de Compostela: Teófilo Edicions, 2014.

31 Ferotin, Marius. "Une lettre inédite de Saint Hugues abbé de Cluny à Bernard d’Agen, archevêque de Tolède (1087)." Bibliothequede l'École des Chartes LXI (1900):339-345; “Complément de la lettre de Saint Hugues, abbé de Cluny à Bernard d'Agen, archevêque de Tolède (1087)." Bibliotheque de l'École des Chartes LXIII (1902): 1-5. También sobre esta carta: Kohnle, Armin. Abt Hugo von Cluny (1049-1109), 229. Sigmaringen: Verlag, 1993.

32 Ver: Reglero de la Fuente, Cluny en España, 344-355.

33 Harris, Julie. "Mosque to Church Conversions in the Spanish Reconquest". Medieval Encounters 3/2 (1997): 158-172.

34 Ver nota 32.

35 Reilly, El reino de León y Castilla bajo el rey Alfonso VI, 80.

36 Ladner, Gerhart B. "The Symbolism of the Biblical Corner Stone in the Mediaeval West." In Images and Ideas in the Middle Ages. Selected Studies in History and Art, vol. I, 171-196. Roma: Edizioni di Storia e Letteratura, 1983.

37 Thunø, Erik. The Apse Mosaic in Early Medieval Rome. Time, Network, and Repetitio, 90-93. Cambridge: Cambridge University Press, 2015.

38 "De tal suerte que ya no sois extranjeros y huéspedes, sino que sois ciudadanos de los santos y familiares de Dios, edificados sobre el fundamento de los apóstoles y de los profetas, siendo piedra angular el mismo Cristo Jesús; en el cual el edificio entero, bien trabado, se alza para formar un templo santo en el Señor; en el cual también vosotros sois coedificados mediante el Espíritu Santo para ser habitación de Dios" (Efesios 2, 20). Esta idea se repite en la primera carta de Pedro: "Vosotros, como piedras vivas, sois edificados como casa espiritual para un sacerdocio santo, para ofrecer sacrificios espirituales, aceptos a Dios por Jesucristo. Por lo cual se 
contiene en la Escritura: «He aquí que yo pongo en Sión una piedra angular, escogida, preciosa, y el que creyere en ella no será confundido»" (1 San Pedro 2, 5-6).

39 Beda el Venerable. "De templo Salomonis". In Patrologia Latina (J. P. Migne, ed.), vol. XCl, col. 735-808, esp. 744-746. París, 1862.

40 En muy buena medida la confusión viene determinada por el extendido uso de la forma 'ceremonia de colocación de la primera piedra' y su comprensión al pie de la letra.

41 Sobre el ritual: Iogna-Prat, Dominique. La Maison de Dieu. Une histoire monumentale de l'Eglise au Moyen Âge, 549-558. París: Éditions du Seuil, 2006; Adámková, Iva. "Qualche considerazione sulla posa delle pietre nelle fondamenta degli edifici sacrali nel Medioevo." Folia philologica 131 (2008): 29-44.

42 Bünz, Enno. "'lapis angularis'- Die Grunstein-legung 1010 als Schlüssel für den mittelalterlichen Kirchenbau von St. Michael in Hildesheim.” In 1000 Jahre St. Michael in Hildesheim. Kirche-Kloster-Stifter (G. Lutz / A. Weyer, ed.), 77-87, esp. 80. Petersberg: Verlag, 2021.

43 Wulf, Christine. "Inschriftenkatalog: Stadt Hildesheim. Katalogartikel in Chronologischer Reihenfolge DI 58: Satadt Hildesheim, nr 6 (2003); Bünz, “lapis angularis”, 82. Ver también: Klápště, Jan. The Czech Lands in Medieval Transformation. 10. Leiden: Brill, 2012.

44 Para otros ejemplos de tipologías de piedras angulares y el rito entorno a ellas: Iva Adámková, Iva. "Qualche considerazione sulla posa delle pietre": 29-44.

45 Falque, Emma (ed.). Historia Compostelana, 189. Madrid: Akal, 1994.

46 Moralejo et alt (ed.). Liber Sancti Jacobi, 570.

47 Senra, José Luis. “Concepto filiación y talleres del primer proyecto catedralicio." In En el principio. Génesis de la Catedral Románica de Santiago de Compostela. Contexto, construcción y programa iconográfico (J. L. Senra, ed.), 58-141, esp. 85-86. Santiago de Compostela, 2014; Senra, J.L. "La iconografía del primer proyecto catedralicio: un tránsito de perfección hacia el hombre espiritual," 164-201, esp. 180-181.

48 Una acomodaticia 'tercera vía' sería habilitar la opción del año 1103 para el registro cronológico de Platerías considerando una pretendida coincidencia de día y mes con la fecha simbólica de la inauguración de las obras del nuevo edificio un 11 de julio de 1078, veinticinco años antes.

49 Para la Concordia de Antealtares ver recientemente: Andrade Cernadas, José Miguel. "La Concordia de Antealtares en su contexto histórico." In Los reyes de Asturias y los orígenes del culto a la tumba del apóstol Santiago (F. J. Fernández Conde / R. Alonso Álvarez, eds.), 109-126. Gijón: Ediciones Trea, 2017.

50 Moralejo, Serafín. "Notas para una revisión de la obra de K. J. Conant." In Kenneth John Conant, Arquitectura Románica da Catedral de Santiago de Compostela, 221-236, esp. 224. Santiago de Compostela: Colexio de Arquitectos de Galicia, 1983; ver asimismo Patrimonio artístico de Galicia y otros estudios, tomo I, 252. Santiago de Compostela: Xunta de Galicia, 2004. Recientemente se ha rechazado ésta hipótesis a partir de considerar que, según el documento, las capillas de San Juan y del Salvador ya estarían materializadas (Castiñeiras González, Manuel A. "La catedral medieval: la dilatada historia de la obra románica y su epílogo medieval” In La Catedral de los Caminos. Estudios sobre Arte e Historia. 261. Santiago de Compostela: Fundación Catedral de Santiago, 2020).

51 Sobre la percepción trascendente o anagógica medieval ver el ya clásico trabajo centrado en la palabra: Ohly, Friedrich. "Vom geistigen Sinn des Wortes im Mittelalter," Zeitschrift für deutsches Alternum und deutsche Literatur 89 (1958): 1-23, esp. 10-11.

52 En torno al contexto de esta pretendida traslación y la fijación de la festividad: Mostert, Marco. The Political Theology of Abbo of Fleury. A Study of the Ideas about Society and Law of the Tenth-Century Monastic Reform Movement, 24-26. Hilversum: Verloren Publishers, 1987.

53 La documentación no permite conocer el paradero del rey más allá del intervalo de enero a mayo de 1078 transcurrido en Sahagún. Ver: Reilly, El reino de León y Castilla bajo el rey Alfonso VI, 143-144. En el mismo mes de mayo el legado pontificio Ricardo de Saint-Victor de Marsella inició su viaje hacia el reino en el que estuvo un año (Reilly. El Reino de león, 125-126); entre sus acciones destaca la presencia en la deposición del obispo de Santiago Diego Peláez en el Concilio de Husillos (1088).

54 Bünz, “lapis angularis", 77-87, esp. 81. Sobre la mitificación sacra de Constantino: Kazhdan, Alexander P. "«Constantin Imaginaire». Byzantine Legends of the Ninth Century about Constantine the Great." Byzantion 57 (1987): 196-250.

55 Hopper, Vincent F. La symbolique médiévale des nombres, 56-57. París: Gérard Momfort, 1995 (Nueva York, 1938). 
57 Su singularidad en la organización decorativa la pone de relieve que fuera mimetizada unos ochenta años después en la última fase constructiva de la catedral: el cierre occidental. Véase la llamada cripta del pórtico.

58 La referencia a las dos columnas de acceso al Templo de Salomón es inevitable. Sobre esta querencia: Moore, Kathryn Blair. The Architecture of the Christian Holy Land. Reception from Late Antiquity through the Renaissance, 91-92. Cambridge: Cambridge University Press, 2017.

59 Senra, "Concepto, filiación y talleres del primer proyecto catedralicio", 102-106; Senra, "La iconografía del primer proyecto catedralicio: un tránsito de perfección hacia el hombre espiritual," 190-199. Interpretados por este autor como probable abreviatura del término teológico SINCERUS asociado al ser espiritual, recientemente se ha considerado que los caracteres $\mathrm{SI} / \mathrm{N}$ presentes en el capitel marmóreo del lado norte serían marcas de cantería de ubicación (indicaría 'sinistra'). Sin embargo ni contamos con capiteles románicos con tales marcas en las caras visibles, ni en un escenario con una mano de obra de operarios analfabetos se usaron marcas silábicas sino siempre 'monográficas'. Por otro lado, sería acción un tanto ingenua por completamente superlativa dado el exiguo tamaño de la capilla en cuyo interior tan solo se incorporaron dos capiteles -únicos de mármoldestinados a su único arco perpiaño. Sobre la posibilidad de responder a marcas de cantería: Castiñeiras González, "La catedral medieval", 257-258.

60 La interpretación de la iconografía del primer proyecto de la catedral configura un apartado realmente complejo pero la representación de animales en estado de agresividad y la inclusión de un capitel con la representación de una suerte de batidor conecta con algunos espacios absidales que incluyen cacerías con un sentido sacro: véase la catedral de Lescar (Pyrenees-Atlantiques) o los prioratos cluniacenses de Ganagobia y de San Andrés de Rosans (Hautes-Alpes). Ver también: Senra, J. L. "La iconografía del primer proyecto catedralicio", 169-175; "Reflexiones en torno a los principios y fundamentos de la catedral románica de Santiago de Compostela (ca. 1075-1105)." Revista Chilena de Estudios Medievales 10 (2016): 9-46.

61 Sobre la extensión de altares dedicados al Salvador ver: García de Castro Valdés, César y Valdés Gallego, José Antonio. "Las inscripciones perdidas de la basílica altomedieval de San Salvador de Oviedo." Espacio, Tiempo y Forma. Historia Medieval 33 (2020): 223-270, esp. 248-257.

62 Para el mundo carolingio: Noble, Thomas F. X. Images, Iconoclasm, and the Carolingians, 336. Philadelphia: University of Pennsylvania Press, 2009; Rabe, Susan A. Faith, Art and Politics at Saint-Riquier. The Symbolic Vision of Angilbert, 124-125. University Pennsylvania Press, 2017.

63 López Alsina, Fernando. La ciudad de Santiago de Compostela en la Alta Edad Media, 137-145. Santiago de Compostela: Centro de Estudios Jacobeos, 1988.

64 En el primer capitel de la girola dispuesto una vez rebasada la capilla de Salvador aparece el obispo Diego Peláez en la misma actitud que, con su habitual sagacidad Serafín Moralejo definió como la recompensa del Paraíso que ambos obtendrían por el impulso a la nueva construcción (Moralejo, Serafín. "Santiago de Compostela: la instauración de un taller románico." In Talleres de arquitectura en la Edad Media, 127-144, esp. 132. Barcelona: Moleiro, 1995.

65 En otro lugar se incidió sobre la idea de una iconografía en absoluto neutra en los capiteles que ornamentan las ventanas laterales de la capilla. En base a la reiteración de leones y grifos, figuras con un muy amplio recorrido de asociación a la realeza (Senra, “La iconografía del primer proyecto catedralicio," 190-199).

66 García de Castro Valdés y Valdés Gallego, "Las inscripciones perdidas de la basílica altomedieval de San Salvador de Oviedo," 244-248.

67 Representaciones muy explícitas en códices y marfiles desde el siglo X. En este sentido véase la placa de marfil de Otón II y Teofano (Musée National du Moyen Age, París) o el folio del Sacramentario de Regensburg con Enrique II (Munich, Bayerische Staatsbibliothek, Clm 4456, fol. 11r) por poner dos conocidos ejemplos.

68 Falque (ed.), Historia Compostelana, 108-109.

69 Sobre esta cuestión: Alexander, Jennifer y Martin, Therese. "Sistemas constructivos en las fases iniciales de la Catedral de Santiago: una nueva mirada al edificio románico a través de las marcas de cantería." In En el principio. Génesis de la Catedral Románica de Santiago de Compostela. Contexto, construcción y programa iconográfico (J. L. Senra, ed.), 142-163. Santiago de Compostela.

70 Las formas poligonales, presentes desde la arquitectura romana, adquirieron un valor de referencia a partir de obras tan significativas como el baptisterio de Letrán (siglo IV), la Daurade de Toulouse (siglo V) o Aquisgrán, por poner ejemplos bien conocidos.

71 Ubieto (ed.), "Primera Crónica Anónima”, 17. 
72 A partir de la presencia del monarca en Sahagún desde fines de octubre hasta la Navidad de ese año Bernard Reilly consideró probable que la inauguración de la nueva estructura se produjo en esos meses (Reilly, El reino de León y Castilla bajo el rey Alfonso VI, 321).

73 Los ecos de la toma de Jerusalén se concretaron de modo exponencial en Sahagún cuando en 1101 llegó a su tesoro litúrgico de manos de Alfonso VI una Cruz con Lignum Crucis regalada al monarca por el emperador bizantino Alexis II (Ubieto (ed.), "Primera Crónica Anónima," 17-18).

74 Herráez Ortega, María Victoria (coord.) Esplendor y decadencia de un monasterio medieval. El patrimonio artístico de San Benito de Sahagún, 62-64. León: Ediciones Universidad de León, 2000. También: Cosmen Alonso, C., Herráez Ortega, M. V. y Valdés Fernández, M. "Alfonso VI y el monasterio de Sahagún. Nuevos testimonios sobre la construcción del templo monástico." De Arte 5 (2006): 29-41.

75 Chapapría Julian Esteban y García Cuetos, María Pilar. Alejandro Ferrant y la conservación monumental en España (1929-1939). Castilla y León y la Primera Zona Monumental, vol. I, 189-215, esp. 202-204. Valladolid: Junta de Castilla, 2007.

76 Ubieto (ed.), "Primera Crónica Anónima," 11.

77 Senra, "En torno a un espacio de evocación," 262

78 Fernández Catón, José María. "Datos para la historia del martirio y del culto de las reliquias de los mártires leoneses Facundo y Primitivo.” In Bivium. Homenaje a Manuel Cecilio Díaz y Díaz, 67-79, esp. 77-78. Madrid: Gredos, 1983.

79 Falque (ed.). Historia Compostelana, 189.

80 Ruiz Albi, Irene. La reina doña Urraca (1109-1126). Cancillería y colección diplomática, doc. 79, 478-480. León: Centro de Estudios e Investigación San Isidoro, 2003.

81 Gambra, Alfonso VI. Cancillería, curia e imperio, II, doc. 189, 481-485.

82 En este último caso véase la evolución de la segunda mitad del siglo XI en territorio franco: Vergnolle, Eliane. L'art roman en France, 143-191. París: Flammarion, 1994.

83 Solar, José. "La antigua iglesia del monasterio de Sahagún y sus bóvedas botareles." Boletín de la Institución Libre de Enseñanza 180 (1884): 232-233; "Algunos rasgos de la iglesia grande del monasterio de Sahagún." Boletín de la Institución Libre de Enseñanza 201 (1885): 184-185.

84 Esta simultaneidad de bloques arquitectónicos de diferentes épocas no era algo ni mucho menos excepcional como lo pone de relieve numerosas construcciones como el Saint-Denis de Suger (ca. 1140) o la iglesia también monástica de Perrecy-les-Forges (Saône-et-Loire) de esta misma cronología.

85 Morales, Ambrosio de. Viage por orden del rey D. Felipe II a los reinos de León, Galicia y Principado de Asturias para reconocer las reliquias de los santos, 36. Madrid: Antonio Marín, 1765. La única vía para darle crédito es que en un montaje tardío, a la primitiva cara frontal argéntea (2,20 m. aproximadamente) se le añadieran las caras laterales también de plata (1,10 m. aproximadamente cada una). Como referencia contemporánea, el altar de Bernardo Gilduino de St. Sernin de Toulouse (1096) medía 2,25 x 1,30cm.

86 Senra, "En torno a un espacio de evocación", 252-262.

87 Senra, "En torno a un espacio de evocación," 243-291, esp. 248 y 263-275. Ver también: "Tournus et Sahagún : une connexion architecturale et institutionnelle à la fin du $\mathrm{XI}^{\mathrm{e}}$ siècle?" Bulletin du centre d'études médiévales d'Auxerre (BUCEMA) 15/1, (2011): 267-281.

88 Herrero de la Fuente, Colección diplomática del monasterio de Sahagún, III doc. 914, 240-242; Ubieto (ed.), "Primera Crónica Anónima," 23.

89 Ubieto (ed.), "Primera Crónica Anónima," 56.

90 Carrero, Eduardo. "El altar mayor y el altar matinal en el presbiterio de la Catedral de Santiago de Compostela. La instalación litúrgica para el culto a un apóstol,” Territorio y Sociedad 8 (2013): 19-52. Sobre el culto a la Magdalena en la catedral de Santiago y su extensión: García Iglesias, José Manuel. "Espacios y percepciones. María Magdalena en la Catedral de Santiago de Compostela." Quintana 2 (2003): 41-56.

91 Senra, José Luis. "«May the Angels Lead You into Paradise»: Staging the Cluniac Liturgy in Medieval Hispanic priories.” Journal of Medieval Iberian Studies 9 (2017): 149-183, esp. 161-162.

92 Cit. Isla Frez, Amancio. Memoria, culto y monarquía hispánica entre los siglos XI y XII, 180. Jaén: Universidad de Jaén, 2006.

93 Williams, John. The Illustrated Beatus. A Corpus of the Illustrations of the Commentary on the Apocalypse. The Eleventh and Twelfth Centuries, 17-25. Londres: Harvey Miller Publishers, 2002. 
94 Moralejo, Serafín. "El mundo y el tiempo en el mapa del beato de Osma." In Patrimonio artístico de Galicia y otros estudios. Homenaje al profesor Serafín Moralejo Álvarez (A. Franco Mata / E. Romero Pose, ed.), tomo II, 237-260. Santiago de Compostela: Xunta de Galicia, 2004.

95 Una síntesis sobre los contenidos y las intenciones del libro IV del LSI: Hebers, Klaus. "El Códice Calixtino, el libro de la Iglesia compostelana.” In Compostela y Europa: la historia de Diego Gelmírez (M. Castiñeiras González, dir.), 122-141. Milán: Skira, 2010.

96 Serafín Moralejo justificó algunas acciones de Carlomagno según la Historia Turpin sobre el fundamento histórico del rey Alfonso VI: concilio magno en Compostela o dotación de la catedral con recursos islámicos obtenidos en campaña bélica (Moralejo, "Santiago de Compostela: la instauración de un taller románico", 138-140).

97 Moralejo et alt. (ed.) Liber Sancti Jacobi, 549. Sobre la exaltación de Carlomagno como fundador de instituciones monásticas al sur de la Galia: Remensnyder, Amy G. Remembering Kings Past: Monastici Foundation Legends in Medieval Southern France. Ithaca: Cornell University Press, 1995. Sobre la instrumentalización de Carlomagno en la península ibérica en fechas más tardías: Molina Figueras, Joan. "Arnau de Montrodon y la Catedral de San Carlomagno. Sobre la imagen y el culto al emperador carolingio en Gerona." Anuario de Estudios Medievales 34 (2004): 417-454.

98 Molina "Arnau de Montrodon," 504.

99 Molina "Arnau de Montrodon," 421-423.

100 López Martínez-Morás, Santiago. Épica y Camino de Santiago. En torno al Pseudo Turpín, 56-65. A Coruña: Seminario de Estudos Galegos, 2002. Como se sabe, este pasaje fue incorporado al ciclo visual de los milagros de Carlomagno en una de las vidrieras de la Catedral de Chartres (Maines, Clark. "The Charlemagne Window at Chartres: New Considerations on Text and Image.” Speculum 52 (1977): 801-823, esp. 813-814.

101 Díaz y Díaz, Manuel C. El Códice Calixtino de la Catedral de Santiago. Estudio codicológico y de contenido, 45-48, n. 52. Santiago de Compostela: Centro de Estudios Jacobeos, 1998.

102 Allí se encontraban hacia 1600 (Guardiola, Juan Benito. Historia del Monasterio de San Benito el Real de Sahagún (según el Ms. 1519 de la BN) (H. S. Martínez, ed.). León: Universidad de León, 2007, _ ).

103 Guardiola, Historia del Monasterio de Sahagún,

104 Si bien desde el siglo XVI se atemperó la sentencia legendaria asociando a Carlomagno solo la fundación del burgo de Sahagún, los monjes resetearon algunos sepulcros atribuyéndolos a algunos colaboradores de Carlomagno. Sobre este asunto ver: Martínez, H. Salvador. "Leyendas épicas carolingias en la ruta jacobea. Milón de Angleris en Sahagún.” Argutorio 31 (2013): 42-53, esp. 52-53, n. 19. También: Senra, José Luis. "Peregrinaciones y reliquias en las rutas hacia Compostela. Héroes y santos a la vera del Camino." Memoria Ecclesiae 18 (2001): 277-292.

105 Gómez Moreno, Historia Silense, LXXV. 